\title{
Türkiye Cumhuriyet Merkez Bankası Para Politikası Reaksiyon Fonksiyonu Tahmini
}

\author{
Erhan Öruç \\ Kocaeli Üniversitesi, İktisadi ve İdari Bilimler Fakültesi, İktisat Bölümü, \\ e.erhanoruc@gmail.com,ORCID:0000-0002-0338-7015
}

$\ddot{O ̈ z}$

Para politikasının kurala mı dayalı olması gerektiği veya politika uygulayıcılarının kişisel görüşlerine dayalı olarak uygulanması gerektiği konusu üzerine dayanan tartışmalar neredeyse bir asrı bulmuştur. $\mathrm{Bu}$ konudaki mihenk taşı ise Taylor kuralının ileri sürülmesidir. Bu kural daha sonraları gelişmekte olan ülkelere uyarlanmıştır. Bu çalışmada Türkiye için Taylor tipi kuralların geçerliliği test edilmiştir. Birim kök test sonuçlarına göre bazı seriler durağan bazıları ise durağan olmadığı için ARDL testi uygulanmıştır. Analizlere göre değiştirilmiş Mohanty-Klau modelini Türkiye Cumhuriyet Merkez bankası davranışını en iyi açıklayan model olarak karşımıza çıkmıştır. Kısa dönemde reel döviz kurundaki değişmenin faiz üzerinde de etkisi vardır. Ayrıca Merkez bankası faiz kararı verirken uzun dönemde çıktı açığını dikkate almaması, önceliğinin fiyat istikrarı olduğunu göstermektedir.

Anahtar Kelimeler: Para Politikası, Taylor Kuralı, Reaksiyon Fonsiyonu, Türkiye, ARDL

JEL Sinıflandırma Kodları: C32, E52, E58

Estimating Monetary Policy Reaction Function for Central Bank of Turkey ${ }^{1}$

\begin{abstract}
There is a famous debate about whether monetary policy follows a rule or discretion which was started a century ago. The mile stone is introducing the Taylor rule. After that, this rule has adapted to the developing countries. In this study, Taylor type rules are validated for Turkish economy. ARDL approach is employed because of unit root test results. According to the results some of variables are stationary, others not. It found that modified Mohanty-Klau model is best for the explaining the behavior of Turkish central bank. In the short run, a change in reel exchange rate has also substantial effect on interest rate. Moreover, while Turkish Central Bank makes decision about interest rate, output gap is ignored means that the priority of the central bank is price stability.
\end{abstract}

Keywords: Monetary Policy, Taylor Rule, Reaction Function, Turkey, ARDL

JEL Classification Codes: C32, E52, E58

\footnotetext{
${ }^{1}$ Extended abstract is presented at the end of the article

Geliş Tarihi (Received): 05.09.2018 - Kabul Tarihi (Accepted): 24.06.2019
}

Atıfta bulunmak için/Cite this paper:

Öruç, E. (2019). Türkiye Cumhuriyet Merkez Bankası para politikası reaksiyon fonksiyonu tahmini. Çankırı Karatekin Üniversitesi İIBF Dergisi. 9 (1), 195-224. 


\section{Giriş}

Geçmişte ve günümüzde ülkeler enflasyonu düşürmek için dönem dönem kendilerini amansız bir mücadele içinde bulmuşlardır. 1930'lardan sonra uygulanan Keynesyen politikalarla enflasyon tekrar dünya ekonomilerinde görülmeye başlanmıştır. 1970'lerde yaşanan iki petrol krizi ekonomilerde enflasyonu ciddi boyutlara taşımış ve enflasyonu düşürmek için çeşitli programlar uygulamışlardır.

Enflasyonu düşürmek için uygulanacak para politikası iki temel prensibe dayanmaktadır. Birincisi uluslararas1 literatürde "discretion policy" olarak adlandırılan ve belirli büyüklükteki bir göstergeyi hedef alan, bu hedef dahilinde para politikasını tamamen politika yapıcıların kararına bırakan, para politikasında takdir yetkisidir. İkincisi ise para politikasının politika yapıcıların inisiyatifine bırakılmayıp belirli bir tepki fonksiyonuna bağlı olarak yürütülmesini esas alan kurallı para politikasıdır. 1990'lara kadar iktisat literatüründe takdir yetkisine dayalı para politikası görüşü hakim iken 1993 yılında Taylor tarafından konferans için hazırlanan ve daha sonra kendi adıyla ithaf edilen kural önerisinden sonra kurallı para politikası üzerine çok sayıda çalışma yapılmıştır.

Bu çalışmada 1993 yılından sonra ortaya çıkan ve uyarlanmış Taylor kuralı olarak adlandırılan üç farklı para politikası kuralı ile orijinal Taylor kuralı merkez bankası reaksiyon fonksiyonu olarak tahmin edilmiştir. 1990-2018 dönemine ait çeyreklik veriler kullanılmışıır. Bu çalışmanın iktisat literatürüne iki önemli katkısı vardır. Birinci katkısı farklı para politikası kuralları arasında karşılaştırma yaparak Türkiye Cumhuriyet Merkez Bankası (TCMB) davranışının hangi modele daha yakın olduğu tespit edilmeye çalışılmış̧ır. İkinci olarak tahmin edilen modellerde nominal faiz oranı ve politika faiz oranı (bankalar arası gecelik faiz oranı) bağımlı değişken olarak kullanılmıştır. Böylece TCMB'nin para politikasına karar verirken nominal faizleri mi yoksa politika faizi mi önemsediği sorusuna cevap aranmıştır².

$\mathrm{Bu}$ çalışma teorik alt yapının özetlenmesi ile devam edecektir. Bir sonraki bölümde ekonomi yazınında ön plana çıkan bu konu hakkında yapılmış çalışmalara yer verilecektir. Dördüncü bölümde kullanılan veriler ve uygulanan metot tanıtılacaktır. Takibinde bulgular değerlendirilecek ve çalışma sonuç bolümü ile bitecektir.

\footnotetext{
${ }^{2}$ Literatürde bazı araştırmacılar politika faiz oranına ulaşamamaları veya başka nedenlerden dolayı bağımlı değişken olarak nominal faiz oranı (mevduatlara uygulanan ortalama faiz oranını) kullanmaktadır. Fakat merkez bankalarının çoğunluğu politikalarını nominal faiz oranına göre değil politika faiz oranına göre belirlediği için, nominal faiz oranlarını kullanan çalışmalın sonuçlarını yorumlarken dikkatli olunması gerekir.
} 


\section{Teorik Altyapı}

Enflasyonu düşürmede en etkili politikaların başında para politikası gelmektedir. Toplam talep üzerinde etkisi dikkate alındığında enflasyonist süreç yaşayan ülkelerde eleştirilerin ilk noktası para politikası olmaktadır. Çünkü ekonomideki talep fazlalığından kaynaklanan enflasyonu düşürme de maliye politikası ile baş rolü oynamaktadır. Hem maliye politikasında hem de para politikasında kural tartışmaları özellikle 1970'lerde yaşanan petrol şokları sonucu hem gelişmiş hem de gelişmekte olan ülkelerde enflasyonun baş göstermesinden sonra alevlenmiştir. Özellikle monetarist iktisatçıların stagflasyonun kaynağının uygulanan yanlış para ve maliye politikalarına bağlamalarından dolayı birçok ekonomist kurallı para ve maliye politikaları üzerine araştırma yapmıştır.

Kurallı para politikasının temelleri aslında 1929 yılında yaşanan büyük buhran sonrasına rast gelmektedir. Dwyer (1995) çalışmasında para politikasının kural üzerine yönetilmesinin ilk tartışmasının 1936 yılında Henry Simons tarafında ileri sürüldügünü belirmiştir. Simons çalışmasında kurallı para politikasının para otoritelerinin veya siyasetçilerin takdir ve inisiyatifinden daha başarılı olduğunu vurgulamıştır. Çünkü özgür girişimciliğin sürdürülebilmesi için istikrarlı yasa ile koruma altına alınmış para politikası kurallarının tanımlanmasının önemli olduğunu belirtmiştir (Dwyer,1995, s. 3).

Diğer taraftan McCallum $(1987,1988)$ çalışmasında ise para politikasının kurallarının uygulamada yaşatacağı bazı sıkıntılara dikkat çekmiştir. Çünkü kurallı para politikasının taşıması gereken dört temel özelliğinden bahsetmiştir. Birinci özellik, kurallar, parasal otorite tarafında doğrudan ve tam olarak belirleyebildiği değişken üzerine kurulmalıdır. Örneğin $\mathrm{M}_{1}$ gibi basit bir değişken bile parasal otoritenin kendisi tarafından kontrol edilemeyen bir değişkendir ve bu değişken üzerinden kural konulması durumunda konulan para politikası kuralının başaralı olmayacağını vurgulamıştır. İkinci özellik ise kuralların finansal endüstride teknik ve yasalarda herhangi bir değişiklik olmayacağı üzerine kurgulanmasının yanlış olacağını belirtmiştir. Çünkü hem finansal endüstrinin hem de finansal kurumların zaman içinde yapısı ve işleyici değişebilmektedir.

Üçüncüsü ise para arzı veya nominal faiz oranının takip ettiği gidişat (rotaları) kendileri için önemli değildir. Bu değişkenler enflasyon oranı, çıktı düzeyi ve işgücü istatistiklerinin iyi performans gösterip göstermediğini ortaya koymada yararlıdır. Bu yüzden bu değişkenleri tek başına politika kuralı olarak kullanmanın doğru olmayacaktır. Son olarak kurallar o ülkenin makroekonomik limitlerin dahilinde olması gerektiğini belirmiştir. Bu dört temel özelliği hiçbir kuralın taşımadığı için parasal büyüklükleri hedeflenmesinin yani para politikasının bu hedefler 
doğrultusunda para otoritesinin inisiyatifine dayanması gerektiğini savunmuştur (McCallum, 1987, ss. 12-13).

1993 yılında Taylor konferans için hazırladığg çalışmasında ABD için bir para politikası kuralı ileri sürmüştür. $\mathrm{Bu}$ öncü çalışmasında Taylor, ABD Merkez bankasının (FED), politika faiz oranını reel gelirden sapma ve hedeflenen enflasyonda sapmalara göre belirlediğini iddia etmiş̧ir ve aşağıdaki formulasyonu önermiştir.

$\mathrm{i}_{\mathrm{t}}=\pi_{\mathrm{t}}+0.5 \mathrm{y}_{\mathrm{t}}+0.5\left(\pi_{\mathrm{t}}-2\right)+2$

$\mathrm{Bu}$ denklemde i ABD merkez bankasının piyasayı fonlama maliyetini yani politika faiz oranını temsil etmektedir. $\pi$ bir önceki yılın aynı çeyreğine göre hesaplanmış enflasyon oranını, y ise hedeflenmiş mili gelirden sapmaları (çıktı açığını) göstermektedir. 2 ise o dönem ABD ekonomisinde beklenen enflasyon oranıdır. Denkleme göre eğer hedeflenen enflasyon gerçekleşir ve çıktığı açı̆̆ı sıfır olursa FED faiz oranını nominal olarak $\% 4$ veya reel olarak $\% 2$ şeklinde belirlemesi gerektiği üzerine görüşünü belirtmiştir.

Taylor'un ileri sürdüğü bu kural aslında McCallum'ın para politikası kuralının olması gereken 4 temel özelliği içinde barındırmaktadır. İleriki yıllarda iktisat literatüründe Taylor kuralı değiştirilerek en yaygın şekli ile kullanılmaya başlanmıştır.

$$
\mathrm{i}_{\mathrm{t}}=\mathrm{r}_{\mathrm{t}}+\pi_{\mathrm{t}}+0.5 \mathrm{y}_{\mathrm{t}}+0.5\left(\pi_{\mathrm{t}}-\pi_{\mathrm{t}}^{\mathrm{e}}\right)
$$

Burada $r$ reel faiz oranını göstermektedir. $\pi^{\mathrm{e}}$ ise beklenen enflasyon oranıdır. İkinci denklemin sağ tarafındaki son ifade enflasyon açı̆̆ 1 olarak tanımlanmaktadır ki bu hedeflenen enflasyondan sapmaları temsil etmektedir. Yani merkez bankaları çıtı açığı azaldıkça ve/veya beklenen enflasyondan sapmalar artıkça piyasayı fonlama maliyetinin arttırması gerektiğini belirten bir kuraldır (Vice Versa). Örneğin ekonomideki enflasyonda artış yaşandığında, FED politika faizini artırmalıdır. Faizler yükseldiğinde para arzı azalacaktır. İkinci aşamada yüksek faiz yatırmaların azalmasına ve millî gelirde düşüş yaşanmasına, işsizliğin artmasına neden olacaktır. Böylece enflasyon düşecektir. Mesela, ekonomi yavaşladığında yani milli gelirdeki artış hızı azalıp işsizlik artı̆̆ında FED faizleri düşürmesi gerekmektedir. Bu durumda faiz düşüşü, para arzında artışa neden olacak. Para arzı artışı ileri dönemde faizleri düşürerek yatırımları artacak reel milli gelirde artış yaşanacaktır. Sonuç olarak işsizlik azalacaktır (Mankiw, 2007, s. 421).

Ball (1999) yaptığı çalışmasında Taylor kuralını açık ekonomiye uyarlamıştır. Açık ekonomilerde Taylor kuralını uyarlamadıkça bu kuralların enflasyon hedeflemesinde 
yetersiz ve vasat kalacağını iddia etmiştir. Bunun temel nedeni ise açık ekonomilerde makroekonomik büyüklükleri faiz oranı kanalı kadar döviz kuru kanalı da etkilemesidir. Para politikasının hem faiz oranından hem de döviz kurundan etkilediğini belirtmiştir. Ayrıca açık ekonomilerde enflasyon hedeflemesinin uzun dönemli enflasyon üzerine olması gerektiğini vurgulamışlardır. Böylece döviz kurunun aşırı dalgalanmasında kaynaklanan enflasyon baskı ortadan kalkacaktır. Bu ülkelerde çıktı düzeyinde ve döviz kurunda aşırı dalgalanmalar yaratacağından dolayı enflasyon hedeflemesinin tehlikeli olduğunu belirtmiştir.

$$
\mathrm{i}_{\mathrm{t}}=\mathrm{f} \pi_{\mathrm{t}}+\mathrm{gy}_{\mathrm{t}}+\mathrm{h}_{0} \mathrm{RER}_{\mathrm{t}}-\mathrm{h}_{1} \mathrm{RER}_{\mathrm{t}-1}
$$

Taylor (2001) yukarıdaki denklemi açık ekonomi için önermiştir. Yukarıdaki denklemdeki gibi i merkez bankası tarafından belirlenmiş faiz oranını (politika faiz oranını), $\pi$ enflasyonu, y çıktı açığını ve RER ise reel döviz kurunu temsil etmektedir. Bu denklemin sabit terimi yoktur. Taylor bunun anlaminin enflasyon hedefinin sıfir olduğu ve reel döviz kuru ile faiz oranlarının uzun dönemli kararlı denge değerlerini temsil ettiğini belirtmiştir (Taylor, 2001, s. 264). Bu denklemde f, $\mathrm{g}, \mathrm{h}_{\mathrm{o}}$ ve $\mathrm{h}_{1}$ katsayıları tahmin edilmesi gereken parametrelerdir. Ĕger $\mathrm{f}=1, \mathrm{~g}>0$ ve $\mathrm{h}_{\mathrm{o}}=0$ ve $\mathrm{h}_{1}=0$ ise bu durumda denklem 3 aslında orijinal Taylor kuralını temsil etmektedir.

$\mathrm{i}_{\mathrm{t}}=\alpha 0+\alpha 1 \pi_{\mathrm{t}}+\alpha 2 \mathrm{y}_{\mathrm{t}}+\alpha 3 \Delta \mathrm{RER}_{\mathrm{t}}+\alpha 4 \Delta \mathrm{RER}_{\mathrm{t}-1}+\alpha 5 \mathrm{i}_{\mathrm{t}-1}$

Mohanty ve Klau (2003) yukarıdaki denklemi kullanarak Taylor kuralı üzerinde değişiklik yapmışlardır. Bu kurala göre enflasyon hedeflemesi sıfır değildir. Bunun yanında reaksiyon fonksiyonunda merkez bankası reel döviz kurunun düzeyine değil reel döviz kurundaki yüzdesel değişmeye tepki vermektedir. Ayrıca para otoritesi bir önceki dönem nominal faiz oranını da dikkate almaktadır.

Bir sonraki aşamada Mohanty and Klau enflasyon yerine enflasyon açığı, reel döviz kurundaki yüzdesel değişme yerine reel döviz kuru serisini kullanarak "açık model" dedikleri alternatif bir model tahmin etmişlerdir. Burada enflasyon açığı ve çıktı açı̆̆ HP filtresi aracılığı ile elde edilmiştir.

$\mathrm{i}_{\mathrm{t}}=\alpha 0+\alpha 1\left(\pi_{\mathrm{t}}-\pi_{\mathrm{t}}^{\mathrm{e}}\right)+\alpha 2\left(\mathrm{y}_{\mathrm{t}}-\mathrm{y}_{\mathrm{t}}^{\mathrm{e}}\right)+\alpha 3 \Delta \mathrm{RER}_{\mathrm{t}}+\alpha 4 \Delta \mathrm{RER}_{\mathrm{t}-1}+\alpha 5 \mathrm{i}_{\mathrm{t}-1}$

Yukarıdaki denkleme göre MB'larının enflasyon açı̆̆ına, çıktı açığına, reel döviz kurundaki değişmeye ve bu değişkenin bir dönem önceki gecikmeli değerine tepki verdiği varsayılmaktadır. Yani açık ekonomilerde merkez bankalarının enflasyon 
açığı, çıktı açığı ve reel döviz kurundaki değişimi dikkate alarak nominal faizlerde değişikliğe gideceklerini düşünülmektedir ${ }^{3}$.

Yukarıda bahsedilen teorik çerçeve göz önüne alındığında gelişmekte olan ülkelerde para politikası kuralı belirlenirken MB'lerin genellikle enflasyon ve döviz kurunu dikkate aldığı anlaşılmaktadır. Buraya kadar kısa bahsedilen teorik çerçeveyi kapsayan ve ekonomi yazınında hem dünya ekonomileri için hem Türkiye için yapılan çalışmalardan bazılarının sonuçlarına bir sonraki bölümde yer verilecektir.

\section{Literatür Taraması}

Para politikası kuralı olarak önerilen Taylor kuralı hakkında uluslararası literatürde ve Türkiye üzerine yapılan çok sayıda çalışma bulunmaktadır. Bazı araştırmacılar MB'nın Taylor kuralını izlediğini bulurken bazıları bu kuralı takip etmediği yçnünde sonuçlar elde etmiştir. $\mathrm{Bu}$ sonuçların elde edilmesinde kullanılan ekonometrik yöntemlerin farklı olmasının yanında, araştırmacıların kullandığı serilerin frekansları ve uzunluğu da değişik sonuçların elde edilmesinde temel etkendir.

Taylor (1993) 1984 - 1992 dönemini kapsayan öncü çalışmasında FED’in uyguladı̆̆ politika faizinin enflasyon açığına ve çıktığı açı̆̆ına tepkisinin 0,5 olarak öneride bulunmuştur. Judd ve Rudebusch (1998) Taylor kuralını 1970-1997 dönemini ABD için tahmin etmişlerdir ${ }^{4}$. 1970Q1-10978Q1, 1979Q3-1987Q2 ve 1979Q3-1997Q4 olarak üç ayrı alt dönemde analizlerini gerçekleştirmişlerdir. Bu dönemlerde sırası file FED başkanları Arthur Burns, Paul Volker ve Alan Greenspan'dir. Orijinal Taylor kuralının Greenspan dönemi için daha uygun olduğunu tespit emişlerdir. Volker dönemi için tahmin edilen çıktı açığ 1 katsayının Taylor'un varsayımının neredeyse iki katı olduğunu tespit etmişlerdir. Volker döneminde tahmin edilen modelin Greenspan dönemindekine göre daha az etkili olduğunu bulmuşlardır. Son olarak Burns dönemindeki tahminin ise oldukça zayıf kaldığını tespit etmişlerdir.

Nelson (2000) 1992 - 1997 yılları arasında İngiltere için Taylor kuralını tahmin etmiştir. 1972 - 1976 yılları arasında yüksek enflasyonun olduğu dönemde nominal faiz oranının enflasyona tepkisinin sıfıra yakın olduğunu bulmuştur. 1979 - 1987 döneminde sıkı para politikası sonucu uzun dönemli denge reel faiz oranında 0,75 puan artış yaşanmasına neden olduğu, bunun sonucunda da Taylor kuralı denkleminin sabitinin arttığını vurgulamışlardır ${ }^{5}$. Sack ve Wieland (2000) Taylor kuralına nominal faiz oranının bir gecikmeli değerini eklemiş̧lerdir. Bu katsayı 0,8 olarak tahmin

\footnotetext{
${ }^{3}$ Denklem 5 değiştirilmiş Mohanty-Klau kuralı olarak bu çalışma boyunca adlandırılacaktır.

${ }^{4}$ Taylor (1993) çalışmasın Taylor kuralını tahmin etmek yerine çıktı açı̆̆ı ve enflasyon açığı için 0,5 değerlerini kendi seçip önermiştir.

${ }^{5}$ Benzer bulgular için bknz Rudebusch (1998) and Clarida, Gali ve Gertler (2000)
} 
edilmiştir. Ayrıca çıktı açığı katsayısı 1,1'dir. Bir dönem önceki çıktı açığı ise nominal faizleri negatif etkilemektedir.

Kim, Osborn ve Sensier (2005) 1960 - 2000 dönemine ait çeyreklik veriler ile ABD için Taylor kuralının doğrusal olup olmadığını test ettiği çalışmasının sonucuna göre Volker dönemi öncesinde yani 1960 - 1979 yılları arasında FED'in doğrusal olmayan politika kuralı takip ettiğini, daha sonraki dönemde ise doğrusal olmadığına dair kanıtların zayıf kaldığını ileri sürmüşlerdir. Shutherland (2010) OECD ülkeleri için para politikası reaksiyon fonksiyonunu tahmin etmiştir. Serilerin bir kısmınım düzeyde bir kısmınım birinci farkı durağan olduğu için ARDL tahmin yöntemini kullanmışlardır. Çek Cumhuriyeti, Hırvatistan, İzlanda ve Meksika için enflasyon ön plana çıkmışken; Kanada, Yeni Zelanda ve ABD için çıktı açığı ön plana çıkmıştır. Genel olarak enflasyonun katsayısının daha yüksek olduğunu belirtmiştir.

Castro (2011) Taylor kuralının doğrusal mı yoksa doğrusal olmayan bir yöntemle mi tahmin edilmesi gerektiğini İngiltere, $A B D$ ve Avrupa bölgesi için analizler yapmıştır. Avrupa bölgesi için 1999:01-2007:12, İngiltere için 1992:01-2007:12 ve ABD için 1982:01-2007:12 dönemlerini içeren veri setlerini kullanmıştır. Avrupa MB'nın ve İngiltere MB'nın davranışını doğrusal olmayan Taylor kuralı ile açıklanabilirken, FED'in davranışı doğrusal Taylor kuralı ile açıklanabileceğine dair sonuçlar elde etmişlerdir. Zheng, Xia ve Huiming (2012), Çin için para politikası reaksiyon fonksiyonunu tahmin etmişılerdir. İki aşamalı maksimum olabilirlik yöntemini kullanılmış ve iki rejime ayrılmıştır. İki rejimi karşılaştırdıklarında asimetrik bir etkinin varlığını gözlemlemişlerdir. İlk rejimde Çin MB'nın (Poeple's Bank of China) enflasyonu hedeflemektedir ve bu dönemde çıktı açığını önemsememektedir. İkinci rejimde ise çıktı açığını önemsemekle birlikte politika kuralı istikrarlı değildir.

Beckmann, Belke ve Dreger (2017) uluslararası yayılma etkisi ve Taylor kuralını incelemişlerdir. İleri sürdükleri düşünce ise bir merkez bankasının (özellikle Fed ve ECB'nin) yapacaği faiz değişikliğinin diğer ülkeleri de etkileyeceği görüşünü ileri sürmüşlerdir. Çeyreklik verileri 1982:01-2008:04 döneminin kapsamaktadır. Önce doğrusal Taylor kuralını tahmin edip Bai-perron yöntemi ile kırılmaları tespit etmişlerdir. Çalışmanın sonucunda faiz oranlarının belirlenmesindeki ve doğrusal olmayan reaksiyon fonksiyonunun gidişatında uluslararası yayılma etkisinin olduğuna dair kanıtlar elde etmişlerdir. Doğrusal olmayan Taylor reaksiyon 
fonksiyonunun açıklama gücünün daha fazla olduğu ve Taylor kuralından sapmaların daha da azaldığını vurgulamışlardır ${ }^{6}$.

Türkiye üzerine yapılan uygulamalı öncü çalışmada ise Kesriyeli ve Yalçın (1998), 1987 - 1998 dönemine ait çeyreklik veriler kullanmıştır. Sonuç olarak Türkiye'de yüksek ve kronik enflasyon olduğu için enflasyonun düşürülmesi yani fiyat istikrarının sağlanmasında Taylor kuralının tek başına başarılı olamayacağını belirtmiştir. Bu yüzden Taylor kuralının düşük enflasyon ve istikrarlı büyümeye sahip ülkelerde geçerli olacağını sonucuna ulaşmışlardır. Çağlayan (2005), 1990:032004:12 dönemini kapsayan çalışmasında Taylor kuralının geçerliliğini Türkiye için test etmiş̧ir. Üretim açığının etkisinin ihmal edilebilecek düzeyde olduğu kanaatine varmıştır. Multinominal logit modeline milli gelirin bir gecikmeli değişkeni eklendiğinde ise üretim ve enflasyon açığının faizlerin düşürülmesinde etkin iken faizlerin yükseltilmesinde etkisinin olmadığı sonucuna ulaşmıştır. Güloğlu ve Erdal (2005) 1987-2004 dönemini aylık veriler kullanarak VAR analizi Taylor kuralı ve reel döviz kuru arasındaki ilişkiyi incelemişlerdir. Model sonucunda tahmin edilen nominal ve reel döviz kuru davranışlarının gerçek döviz kuru davranışına yakın olduğunu tespit etmişlerdir. Fakat modellerinde çıktı açığı ve enflasyon farkı ile reel döviz kuru arasındaki korelasyonun düşük çıktığını belirtmiş̧lerdir.

Yazgan ve Yılmazkuday (2007), çalışmaları Türkiye ve İsrail üzerinedir. Türkiye için 2001M8-2004M4 dönemi, İsrail için ise 1999M1-2002M12 dönemini tahmin edilmiştir. Basit Taylor kuralının her iki ülkede merkez bankalarının davranışlarını açıklamada başarılı olduğunu ortaya koymuşlardır. Para arzındaki artış, reel döviz kuru, döviz kurunun denge değerinden sapmaları ve nominal döviz kurundaki değişme modele eklendiğinde bu değişkenlerin tümünün istatistiksel olarak anlamlı olmadığını belirtmişlerdir. Berument ve Taşçı (2007), ileriye dönük Taylor kuralını Türkiye verilerini kullanarak 1990:01-2000:10 dönemi için tahmin etmişlerdir. Bankalararası borç verme oranı ile döviz kurundaki değiş̧me arasındaki fark politika aracı olarak alındığında uygulama sonuçları TCMB'nin uluslararası rezervleri, milli geliri ve $\mathrm{M}_{2}$ parasal büyüklükteki artışı dikkate aldığını, fakat bu değişkenlerin ileriye dönük değil, o dönemdeki değerlerine veya geçmiş değerlerine göre politika oluşturduğuna dair kanıtlarına ulaşmışlardır.

Zortuk'un (2007) çalş̧ması TCMB'nin açık ve örtük enflasyon hedeflemesinin uygulandığı dönemi kapsamaktadır. 2001:08-2016:12 aylık veri setini kullanmıştır. Sınır testi sonuçlarına göre Taylor kuralının geçerli olabileceği yönünde sonuçlar elde

\footnotetext{
${ }^{6}$ Diğer bazı ülke çalışmaları için bknz İsviçre için (Perruchoud, 2009; Nitschka ve Markov, 2016), Japonya için (Miyazawa, 2011; Depalo, 2006); Kolombiya için (Villa, Misas ve Giraldo, 2014), Suudi Arabistan için (Almounsor, 2015), Tunus için (Sghaier, 2012)
} 
etmiştir. Kısa vadeli faiz oranlarını açıklamada değişkenlerin etkisinin varlığına dair bulgulara ulaşılmıştır. Türkiye'de Taylor kuralının geçerli olduğu sonucuna ulaşan diğer bir çalışma ise Onur (2008) tarafından kaleme alınmıştır. 1980-2005döneminde enflasyon ve faiz arasında güçlü bir ilişkinin varlığını bulurken 2001 sonrasında uygulanan para politikasın kuralının devam ettirilmesi gerektiği yönünde sonuca ulaşmıştır.

Çağlayan ve Astar (2010) gelişmiş ülkelerde enflasyon hedefi uygulamasında merkez banklarının Taylor kuralı uygulaması hem enflasyonu düşürüp sabitleme de hem de üretim düzeyinde istikrara neden olduğunu bulmuşlardır. Yüksek enflasyona sahip gelişmekte olan ülkelerde sadece Taylor kuralının uygulanması dengeli ve düşük enflasyona ulaşmada yetersiz kaldığını tespit etmişlerdir. Bazı gelişmekte olan ülkelerde katsayıların anlamsız olduğu ve Taylor kuralına döviz kuru eklendiğinde modelin çok fazla çalışmadığı yönünde deliller elde etmişlerdir. Yıldırım, Lopçu, Çakmaklı ve Özkan, (2010) yaptıkları çalışmaları 1990Q1-2008Q2 dönemini kapsamaktadır. Vektör otoregresif analizi kullanmışlar ve tüfe veya deflatör kullanımının herhangi bir değişikliye yol açmayacağı, çıktı açığının enflasyon üzerine anlamlı bir etkisinin olmadığını, ayrıca çıktı açığını nominal faizlerin üzerinde de etkisinin olmadığı sonucuna ulaşmışlardır.

Gözgör (2012), Taylor kuralını ve Hibrit McCallum-Taylor kuralının merkez bankasının davranışı açıklamak için tahmin etmiştir. 2003:01-2012:01 dönemini için çeyreklik veriler kullanmıştır. Modelde nominal döviz kurları kullanılmıştır. Çıktı açığının etkisi yüzde 1.8 iken enflasyonun etkisi yüzde 14 olarak bulunmuştur. Faiz oranını gecikmeli değeri ise 0.95 gibi oldukça yüksek bir rakamdır. Nominal gelir açığının katsayısı 0,15 iken nominal döviz kurunun etkisi Hibrit MacCullum-Taylor modelinde ihmal edilebilir olduğunu iddia etmişlerdir. Faiz oranının gecikmeli değeri birin üzerindedir ${ }^{7}$. Sonuç olarak Taylor kuralının merkez bankasının davranışını daha iyi açıkladığı sonucuna ulaşmıştır. Ardor ve Varlık (2014), yeni Keynesyen para politikası kurallarını Türkiye ekonomisi için geçerliliğini sorgulamıştır. 3 farklı Taylor kuralı tahmin edilmiştir. Veri seti çeyreklik olup 2002-2014 yıllarını kapsamaktadır. Merkez bankasının faiz politikasının ileriye dönük Taylor kuralına daha uygun olduğunu bulmuşlardır. Ayrıca TCMB'nin politika faiz oranında aşırı iniş ve çıkışların olmaması gayretinde olduğunu vurgulamışlardır.

Albayrak ve Abdioğlu (2015), yaptıkları çalışmaları 2002 - 2015 dönemini ve alt periyodlarını kapsamaktadır. Merkez bankasının çıktı açığından daha çok enflasyondaki değişmeleri dikkate aldığını tespit etmişlerdir. 2008 - 2014 alt döneminde ise ileriye ve geriye dönük para politikası reaksiyon fonksiyonlarını takip

\footnotetext{
${ }^{7} \mathrm{Bu}$ çalışmada nominal döviz kurları alındığı için yorumlarken oldukça dikkatli olunmalıdır.
} 
ettiği sonucuna ulaşmışlardır. Bal, Tanrı̈ver ve Erdoğan (2016) 2001-2016 dönemini aylık veriler aracılığıyla incelemişlerdir. Çıktığı açığı değişkeni ve enflasyon aracı değişkenini hesaplarken Beveridge ve Nelson ayrıştırma yöntemini uygulanmışlardır. Enflasyon açığının katsayısı istatistiki olarak anlamlı iken çıktı açığı ve döviz kuru açığının katsayılarının istatistiki olarak anlamı olmadığı sonucuna ulaşmışlardır. Özcan (2016), Taylor kuralının asimetrik etkilerini incelediği çalışması 2001Q1 2013Q2 dönemini kapsamaktadır. Eşik regresyon modelini kullanmış olup, çıktı açı̆̆ı kısa vadeli faiz oranlarını en fazla yüksek enflasyon döneminde etkilediğini tespit etmişlerdir ${ }^{8}$.

Yukarıda hem dünyada hem de Türkiye'de yapılan Taylor kuralı üzerine çalışmalardan bazılarına yer verilmiştir. Literatürde çok sayıda türü olan bu kural üzerinde özellikle gelişmekte olan ülkeler için henüz bir konsensüs sağlanamamıştır. Bir sonraki bölümde bu çalışmada kullanılan veri seti ve ekonometrik yaklaşımlar tanitılacaktır.

\section{Uygulama Tekniği}

Teorik bölümde aktarıldığı üzere çeşitli Taylor tipi kuralların Türkiye ekonomisi için geçerliliğinin sorgulanması bu çalışmanın temel amacıdır. Çalışmada zaman serilerini içereceğinden dolayı öncelikle veriler tanıtılacak daha sonra kullanılacak ekonometrik model tanitılacaktır.

\subsection{Veri Seti ve Değişkenler}

Bir önceki bölümde kurallı para politikası hakkında yapılan uygulamalı çalışmalara yer verilmiştir. Bu çalışmada merkez bankasının reaksiyon fonksiyonunun tahmini için çıktı açığı (GSYIHH verisinden), enflasyon açığ (tüketici fiyat endeksi verisinden), reel döviz kuru, mevduatlara uygulanan faiz oranı ve bankalararası gecelik borç verme oranı verilerinden yararlanılmıştır. Tüm veriler çeyreklik olup, 1990:01-2018:01 dönemini kapsamaktadır. Faiz oranı verisi hariç diğer veriler mevsimsel etkilerden arındırılmıştır. Veri setinin tamamı TCMB'nin elektronik veri dağıtım sisteminden temin edilmiştir.

\subsection{Ekonometrik Yöntemler}

Bu çalışmada çıktı açığı ve enflasyon açığı kullanılacağı için Hodric ve Prescott (1997) tarafindan geliştirilen ve seriler trend ve döngüsel (cyclical) olarak iki ayrı

\footnotetext{
8 Türkiye üzerine yapılan diğer çalışmalar ise Ongan (2004), Aklan and Nargeleçekenler (2008), Kaytanc1 (2008), Omay and Hasanov (2010), Pehlivanoğlu (2012), Demirbaş ve Kaya (2012), Gögül ve Songur (2016)
} 
seriye dönüştüren filtreleme yöntemi kullanılacaktır. Örneğin $y_{t}$ gibi bir serimiz olduğunu varsayalım. HP filtresi bu seriyi trend $\left(\mu_{\mathrm{t}}\right)$ ve döngüsel kısım $\left(\mathrm{y}_{\mathrm{t}^{-}} \mu_{\mathrm{t}}\right)$ olarak iki kısma ayıracaktır. Örneğin GSYİH verisini HP filtresi yardımıyla trend ve döngüsel olmak üzere iki ayrı seriye dönüştürdüğümüzde döngüsel kısım çıktı açığını oluşturacaktır. Enflasyon açığı da benzer şekilde HP filtresi yardımıyla trend ve enflasyon açığı olarak iki parçaya ayrılacaktır.

Bir sonraki aşamada zaman serileri kullandığımız için bu serilerin durağan olup olmadığı araştırılması gerekmektedir. Durağan olmayan zaman serileri regresyona tabi tutulduğunda regresyon sonuçları üzerinde şüpheye düşülebilmektedir. 1974 yılında Granger ve Newbold (1974) ABD için bir seri hariç 34 makroekonomik serinin birim kök içerdiğini ekonometrik olarak göstermiştir. Bu durağan olmayan serileri ile ekonometrik analiz yapılırsa serilerin içerdiği trend etkileşim ile $\mathrm{R}^{2}$ olması gerekenden oldukça yüksek bir değer çıkacaktır. Ayrıca bu regresyondan elde edilen $\mathrm{t}$ değerlerine güvenilemez.

$\mathrm{Bu}$ çalışmada literatürde en fazla tercih edilen iki birim kök testi olan Dickey ve Fuller (1979) tarafından geliştirilen Genelleştirilmiş Dickey Fuller (ADF), PhilipsPerron (1988) uygulanacaktır. Birim kök testinden sonrasında ise reaksiyon fonksiyonu denklemleri gecikmesi dağıtılmış otoregresif model (Autoregressive Distributed Lag (ARDL)) yardımıyla tahmin edilecektir. ARDL, açıklayıcı değişken ve bağımlı değişkenin gecikmeli değerleri ile birlikte regresyona tabi tutulmasıdır. Uzun dönemden beri kullanılmasına rağmen Pesaran ve Shinn (1999) değişkenler arasında koentegrasyon ve uzun dönemli ilişkiyi araştırmasından sonra çok daha popüler hale gelmiştir. (Eviews, 2014, s. 283)

Son aşamada ise sınır testi yaklaşımı ile açıklayıcı değişkenler ile bağımlı değişkenler arasında uzun dönemli ilişki yani koentegrasyon olup olmadığı tespit edilecektir. ARDL testinde önemli bir nokta ise tahmin edilen katsayıların durağan olup olmamasıdır. Bu ise cusum testleri ile bu tahmin edilen katsayılarda kırılma olup olmadığı ortaya konulacaktır. Dikkat edilmesi gereken bir başka nokta ise model ARMA yapısında olduğu için, modellerin durağanlığı polinominal ters kökler bulunup birim çember üzerinde gösterilecektir. ARDL modeli durağan olabilmesi için polinominal ters köklerin tümü birim çemberin içinde olması gerekmektedir.

\section{Ekonometrik Bulgular ve Yorumlar}

$\mathrm{Bu}$ makalenin temel konusu merkez bankasının politika faizi belirlemedeki davranışını açıklamada Taylor kuralının yeterli olup olmadığıdır. Bu bağlamda teorik kısımda görüleceği üzere orijinal Taylor kuralı zaman içinde bazı değişikliklere uğramıştır. Özellikle orijinal Taylor kuralının kapalı ve gelişmiş ülkelere yönelik 
olduğu kanısı ekonomi literatüründe yaygındır. Daha sonra Taylor başta olmak üzere gelişmekte olan ülkeleri için yapılan analizlere döviz kurları da eklenmiş̧ir.

Bu bağlamda çalışmada enflasyon, reel gayri safi yurtiçi hasıla (GSYIH), reel döviz kuru ve politika faizi olarak bankalararası borç verme faizi serileri kullanılmıştır. Politika faizine alternatif olarak mevduatlara uygulanan faiz oranı içinde her bir model tahmin edilmiştir. Bu beş seri zaman unsurunu içerdiği için öncelikle bu serilerin düzeyde ve birinci farklarının durağan olup olmadığına dair birim kök testleri uygulanacaktır.

Uygulanan ilk birim kök tesi olan ADF test sonuçları Tablo 1'de verilmiştir. ADF testinde en önemli problem uygun gecikme sayısıdır. Uygun gecikme sayısı modelde ardışık bağımlılı̆̆ı önleyecek kadar yeterli, serbestlik derecesini çok düşürmeyecek kadar az olmalıdır. Bu konuda herhangi bir uzlaşı yoktur. En çok güvenilir yöntem ise olabildiğince az veya çok sayıda gecikme modele dahil edildiğinde aynı sonucu vermesi, o testin güvenilirliğini arttıracaktır9.

Tablo 1. ADF Test Sonuçları

\begin{tabular}{|c|c|c|c|c|c|c|}
\hline & \multicolumn{3}{|c|}{ ENF } & \multicolumn{3}{|c|}{ FAİZ } \\
\hline Gecikme & $\mathrm{N}$ & $\mathrm{C}$ & $\mathrm{C} / \mathrm{T}$ & $\mathrm{N}$ & $\mathrm{C}$ & $\mathrm{C} / \mathrm{T}$ \\
\hline 1 & -1.286 & -1.227 & -2.413 & -1.075 & $-1.444 *$ & $-3.527 * *$ \\
\hline 4 & -1.215 & -0.698 & -1.648 & -0.97 & -0.797 & -2.764 \\
\hline \multirow[t]{3}{*}{8} & -1.566 & -0.855 & -1.19 & -1.293 & -0.63 & -1.912 \\
\hline & \multicolumn{3}{|c|}{ TERK } & \multicolumn{3}{|c|}{ POL_F } \\
\hline & $\mathrm{N}$ & $\mathrm{C}$ & $\mathrm{C} / \mathrm{T}$ & $\mathrm{N}$ & $\mathrm{C}$ & $\mathrm{C} / \mathrm{T}$ \\
\hline 1 & -0.322 & $-2.234 * *$ & -2.342 & $-2.328 * *$ & $-3.338 * * *$ & $-6.143^{* * * *}$ \\
\hline 4 & -0.151 & $-1.44^{*}$ & -0.988 & -1.361 & $-1.517 *$ & $-3.449 * *$ \\
\hline \multirow[t]{3}{*}{8} & -0.097 & -1.153 & -0.355 & -1.195 & -0.881 & -2.495 \\
\hline & \multicolumn{3}{|c|}{ RGDP } & & & \\
\hline & $\mathrm{N}$ & $\mathrm{C}$ & $\mathrm{C} / \mathrm{T}$ & & & \\
\hline 1 & 0.57 & -1.168 & $-6.834 * * *$ & & & \\
\hline 4 & 3.446 & 1.447 & -1.426 & & & \\
\hline 8 & 3.322 & 1.665 & -1.12 & & & \\
\hline
\end{tabular}

* Tabloda ADF test sonuçlarına göre \%10, \%5 ve \%1 seviyesinde serilerin durağanlığı sırası ile *, **,*** gösterilmiştir. Kritik değerler MacKinnon (1994) göre değerlendirilmiştir.

\footnotetext{
${ }^{9} \mathrm{ADF}$ testinde 0 ile 12 gecikme arası uygulanmasına rağmen makalede fazla yer kaplamaması için 1,4 ve 8 gecikmeli sonuçlara yer verilmiştir. 8 gecikme ile 12 gecikme arasında tüm serilerde herhangi bir değişiklik olmadığı gözlemlenmiştir. Yazardan istenildiği takdirde tüm sonuçlar gönderilebilir.
} 
Enflasyon verisine baktığımızda yalın model, sabit içeren model ve hem sabit içeren hem de trend içeren model için düzeyde serinin birim kök içerdiğini iddia eden boş hipotez reddedilememektedir. Benzer şekilde nominal faizler içinde aynı şeyi söyleyebiliriz. 1 gecikme alındığında sabit içeren modelde $\% 10$ düzeyinde durağan iken, hem sabit hem de trend içeren modelde ise $\% 5$ seviyesinde durağandır. Diğer tüm gecikmelerde serilerin birim kök içerdiği boş hipotez reddedilmemektedir. Reel GSYİH serisi ise sadece sabit ve trend içeren modelde bir gecikmeli durumda düzeyde durağan iken diğer tüm gecikmeli durumlarda durağan değildir. REK serisi ve politika faiz oranı içinde benzer yorumlar yapılabilir.

Tablo 2. Phillips-Perron Test Sonuçları

\begin{tabular}{|c|c|c|c|c|c|c|}
\hline \multirow[b]{3}{*}{ Gecikme } & \multicolumn{6}{|c|}{ ENF } \\
\hline & \multicolumn{3}{|c|}{$\mathrm{Z}(\mathrm{t})$} & \multicolumn{3}{|c|}{$\mathrm{Z}$ (rho) } \\
\hline & $\mathrm{N}$ & $\mathrm{C}$ & $\mathrm{C} / \mathrm{T}$ & $\mathrm{N}$ & $\mathrm{C}$ & $\mathrm{C} / \mathrm{T}$ \\
\hline 1 & -1.921 & -2.706 & -10.1 & -1.227 & -1.136 & -2.303 \\
\hline 4 & -1.884 & -2.651 & -10.391 & -1.222 & -1.124 & -2.335 \\
\hline 8 & -1.581 & -2.002 & -8.74 & -1.188 & -0.969 & -2.152 \\
\hline \multirow[b]{3}{*}{ Gecikme } & \multicolumn{6}{|c|}{ TERK } \\
\hline & \multicolumn{3}{|c|}{$\mathrm{Z}(\mathrm{t})$} & \multicolumn{3}{|c|}{$\mathrm{Z}$ (rho) } \\
\hline & $\mathrm{N}$ & $\mathrm{C}$ & $\mathrm{C} / \mathrm{T}$ & $\mathrm{N}$ & $\mathrm{C}$ & $\mathrm{C} / \mathrm{T}$ \\
\hline 1 & -0.218 & 10.636 & -14.636 & -0.319 & -2.355 & -2.499 \\
\hline 4 & -0.137 & -8.653 & -12.28 & -0.248 & -2.135 & -2.257 \\
\hline 8 & -0.08 & -7.769 & -11.573 & -0.183 & -2.029 & -2.179 \\
\hline \multirow[b]{3}{*}{ Gecikme } & \multicolumn{6}{|c|}{ RGDP } \\
\hline & \multicolumn{3}{|c|}{$\mathrm{Z}(\mathrm{t})$} & \multicolumn{3}{|c|}{$\mathrm{Z}$ (rho) } \\
\hline & $\mathrm{N}$ & $\mathrm{C}$ & $\mathrm{C} / \mathrm{T}$ & $\mathrm{N}$ & $\mathrm{C}$ & $\mathrm{C} / \mathrm{T}$ \\
\hline 1 & 0.516 & -4.307 & $-67.64 * * *$ & 0.418 & -1.408 & $-6.72 * * *$ \\
\hline 4 & 1.036 & -1.65 & $-65.71 * * *$ & 1.502 & -0.818 & $-6.66 * * *$ \\
\hline 8 & 1.103 & -1.652 & $-84.07 * * *$ & 1.885 & -0.819 & $-7.25 * * *$ \\
\hline
\end{tabular}

* Tabloda ADF test sonuçlarına göre $\% 10, \% 5$ ve $\% 1$ seviyesinde serilerin durağanlığı sırası ile *, **,*** gösterilmiştir. Kritik değerler MacKinnon (1994) göre değerlendirilmiştir.

Tablo 2'de ise Phillips - Perron birim kök testi sonuçlarına yer verilmiştir. Enflasyon ve REK serilerinin farklı gecikme sayıları alınsa dahi düzeyde durağan olmadığını iddia eden boş hipotez reddedilemez. Faiz oranı serisi ise hem yalın modelde hem de sabitli modelde bu seriler düzeyde durağan değil iken birim kök testine trend dahil edildiğinde serinin düzeyde durağan olduğu sonucuna ulaşılmıştır. Aynı yorum reel GSYİH içinde yapılabilir. Bankalararası gecelik faiz oranı serisi ise tüm gecikmeli 
değerleri için serinin düzeyde durağan olduğu sonucuna ulaşılmaktadır. Bu birim kök testinin sonuçları ister $z(t)$ isterse $z(r h o)$ istatistik testleri ele alınsm, herhangi bir değişiklik gözlemlenmemiştir ${ }^{10}$.

Tablo 2 (devam). Phillips-Perron Test Sonuçları

\begin{tabular}{|c|c|c|c|c|c|c|}
\hline \multirow[b]{3}{*}{ Gecikme } & \multicolumn{6}{|c|}{ FAİZ } \\
\hline & \multicolumn{3}{|c|}{$\mathrm{Z}(\mathrm{t})$} & \multicolumn{3}{|c|}{$\mathrm{Z}$ (rho) } \\
\hline & $\mathrm{N}$ & $\mathrm{C}$ & $\mathrm{C} / \mathrm{T}$ & $\mathrm{N}$ & $\mathrm{C}$ & $\mathrm{C} / \mathrm{T}$ \\
\hline 1 & -2.019 & -5.248 & $-21.374 * *$ & -1.118 & -1.56 & $-3.61 * *$ \\
\hline 4 & -1.441 & -3.658 & $-18.438^{*}$ & -0.994 & -1.282 & $-3.41 *$ \\
\hline 8 & -1.154 & -3.126 & $-18.266^{*}$ & -0.934 & -1.174 & $-3.40 *$ \\
\hline \multirow[b]{3}{*}{ Gecikme } & \multicolumn{6}{|c|}{ POL_F } \\
\hline & \multicolumn{3}{|c|}{$Z(t)$} & \multicolumn{3}{|c|}{$\mathrm{Z}$ (rho) } \\
\hline & $\mathrm{N}$ & $\mathrm{C}$ & $\mathrm{C} / \mathrm{T}$ & $\mathrm{N}$ & $\mathrm{C}$ & $\mathrm{C} / \mathrm{T}$ \\
\hline 1 & $-10.41 * *$ & $-22.28 * * *$ & $-54.54 * * *$ & $-2.35 * *$ & $-3.44 * *$ & $-5.91 * * *$ \\
\hline 4 & $-6.433^{*}$ & $-16.84 * *$ & $-45.94 * * *$ & $-1.89 *$ & $-3.02 * *$ & $-5.58 * * *$ \\
\hline 8 & $-6.378^{*}$ & $-19.41 * *$ & $-47.69 * * *$ & $-1.88^{*}$ & $-3.23 * *$ & $-5.65 * * *$ \\
\hline
\end{tabular}

* Tabloda ADF test sonuçlarına göre $\% 10, \% 5$ ve $\% 1$ seviyesinde serilerin durağanlığı sırası ile *, **,*** gösterilmiştir. Kritik değerler MacKinnon (1994) göre değerlendirilmiştir.

Tüm serilerin birinci farkları da birim kök testlerine tabi tutulmuştur. Bu çalışmada kullanılan serilerin birinci farkının gecikme sayısı farketmeksizin düzeyde durağan olduğu istatistiki olarak elde edilmiştir ${ }^{11}$. O halde enflasyon ve reel döviz kuru serilerinin düzeyde birim kök içerdiğini ve birinci farklarının durağan olduğunu ortaya koymuş olduk. Yani bu serilerin sura derecesi (integrated order) bir [I(1)] olarak ifade edilir. Fakat kalan üç seri içinde aynı yorumu yapmak için güçlü kanıtlar elde edilememiştir. Özellikle politika faiz oranının düzeyde durağan olması bu serinin sıra derecesinin sıfır $[\mathrm{I}(0)]$ olduğu sonucuna ulaşılmaktadır. Serilerimiz bazıları düzeyde durağan bazılarının birinci farkı durağan olduğu için ARDL uygulamak gerekmektedir.

ARDL tahmin sonuçları Tablo 3'de verilmiştir. Model 1, ilk defa Taylor tarafındanönerilen ve faizin reel faize, enflasyona bire bir tepki verdiği fakat çıktı açığı ve enflasyon açı̆̆ katsayısının 0.5 olarak önerilen model tahmin edilmiş̧ir. $\mathrm{Bu}$

\footnotetext{
${ }^{10}$ Uygulamalı çalışmalarda genellikle ADF ve PP testlerine ek olarak bir de Kwiatkowski, Phillips, Shin ve Schmidt tarafindan 1992 yılında geliştirilen ve KPSS birim kök testi olarak adlandırılan, standart birim kök testlerine göre boş ve alternatif hipotezlerin yer değiştirdiği birim kök testi sonuçları ADF ve PP birim kök testi sonuçları ile uyuşmaktadır. Yazardan e-mail ile istenebilir.

${ }^{11}$ İstatistiki sonuçlar sayfa tasarrufu amacıyla rapor edilmemiştir. Yazardan e-mail ile istenebilir.
} 
modelde Taylor gibi enflasyon ve reel faiz oranı bir kabul edilerek işlem yapılmıştır. Model 2 ise Taylor (2001) çalışmasında açık ekonomiler için önerdiği kural tahmin edilmiştir. Model 3'de ise Mohanty ve Klau'nun merkez bankası davranışlarının enflasyon, çıktı açığına, reel döviz kurundaki değişmeye ve bu değişkenin bir gecikmeli değerine tepki verdiğini varsaydığ ise merkez bankasının döviz kurundaki değişme oranını değil döviz kurunun düzeyini

Tablo 3. ARDL Testi Sonuçları

\begin{tabular}{|c|c|c|c|c|c|c|c|c|}
\hline \multirow{2}{*}{ Değişken } & \multicolumn{2}{|c|}{ Model 1} & \multicolumn{2}{|c|}{ Model 2} & \multicolumn{2}{|c|}{ Model $3^{\text {at }}$} & \multicolumn{2}{|c|}{ Model 4} \\
\hline & A & $\mathrm{B}$ & A & $\mathrm{B}$ & A & $\mathrm{B}$ & A & B \\
\hline \multirow[b]{2}{*}{ Enf } & 1 & 1 & 0.8516 & 0.4706 & 0.8359 & 0.4683 & - & - \\
\hline & - & - & $\begin{array}{c}(0.0907)^{*} \\
* *\end{array}$ & $\begin{array}{c}(0.1487)^{*} \\
* *\end{array}$ & $\begin{array}{c}(0.1001)^{*} \\
* *\end{array}$ & $\begin{array}{c}(0.1488)^{*} \\
* *\end{array}$ & - & - \\
\hline \multirow{2}{*}{ Reel Faiz } & 1 & 1 & - & - & - & - & - & - \\
\hline & - & - & - & - & - & - & - & - \\
\hline \multirow{2}{*}{$\begin{array}{l}\text { Çıktı } \\
\text { Açı̆ı } 1\end{array}$} & 0.010 & - & -19.6197 & -36.163 & -17.228 & -35.881 & -20.051 & -25.276 \\
\hline & $(0.007)$ & - & $(15.235)$ & $(27.178)$ & $(15.116)$ & $(27.118)$ & $(7.15)^{* * *}$ & (18.424) \\
\hline \multirow{2}{*}{$\begin{array}{c}\text { Enflasyon } \\
\text { Açı̆̆ }\end{array}$} & -0.00005 & -0.6779 & - & - & - & - & 0.5654 & -0.4899 \\
\hline & $(0.00005)$ & $(0.2) * * *$ & - & - & - & - & $(0.219) * *$ & $(0.2)^{* * *}$ \\
\hline \multirow{2}{*}{ REK } & - & - & -0.2955 & 1.3669 & - & - & -0.4199 & -1.6246 \\
\hline & - & - & $(0.1522)^{*}$ & $(0.7238)^{*}$ & - & - & $(0.12)^{* * *}$ & $(0.3)^{* * *}$ \\
\hline \multirow{2}{*}{$\mathrm{REK}_{\mathrm{t}-1}$} & - & - & 0.3601 & 1.3669 & - & - & 0.2768 & 1.3557 \\
\hline & - & - & $(0.151)^{* *}$ & $(0.7238)^{*}$ & - & - & $(0.07)^{* * *}$ & $(0.2)^{* * *}$ \\
\hline \multirow{2}{*}{$\triangle \mathrm{REK}$} & - & - & - & - & -0.3205 & -1.3635 & - & - \\
\hline & - & - & - & - & $(0.1838)^{*}$ & $(0.7223)^{*}$ & - & - \\
\hline \multirow{2}{*}{$\Delta \mathrm{REK}_{\mathrm{t}-1}$} & - & - & - & - & 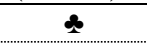 & $\&$ & - & - \\
\hline & - & - & - & - & 2 & 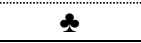 & - & - \\
\hline \multirow[b]{2}{*}{$\dot{\mathrm{I}}_{\mathrm{t}-1}$} & - & - & - & - & 0.5627 & 0.4648 & 0.7522 & 0.5575 \\
\hline & - & - & - & - & $\begin{array}{c}(0.0504)^{*} \\
* *\end{array}$ & $\begin{array}{c}(0.0712)^{*} \\
* *\end{array}$ & $\begin{array}{c}(0.0889)^{*} \\
* *\end{array}$ & $\begin{array}{c}(0.0485) \\
* * *\end{array}$ \\
\hline \multirow{2}{*}{ Sabit } & - & - & - & - & 6.8296 & 0.5941 & 15.584 & 26.712 \\
\hline & - & - & - & - & $(1.49)^{* * *}$ & $(1.2887)$ & $(9.101)^{*}$ & $(11.2)^{* *}$ \\
\hline $\begin{array}{c}\text { ARDL } \\
\text { Gecikme }\end{array}$ & $(2,3,0)$ & $(3,0,0)$ & $(5,6,1,1)$ & $(7,0,3,1)$ & $(5,6,1,0)$ & $(7,0,3,0)$ & $(4,1,8,1)$ & $(7,3,7,1)$ \\
\hline $\mathrm{R}^{2}$ & 0.110 & 0.262 & 0.959 & 0.809 & 0.959 & 0.809 & 0.953 & 0.843 \\
\hline Düz. R2 & 0.058 & 0.234 & 0.952 & 0.782 & 0.952 & 0.782 & 0.944 & 0.804 \\
\hline
\end{tabular}

ve \%10 düzeyinde istatistiksel olarak anlamlı olduğunu göstermektedir. Modeli seçerken Akaike bilgi Kriteri tercih edilmiştir. Ayrıca model Newey-West yöntemiyle tahmin edildiği için otokorelasyon ve farklı varyans testleri uygulanmamıştır.

- Teorik kısımda modelin birinci geçmişi olmasına rağmen ARDL modelini tahmin ederken gecikmeli değerler olduğundan dolayı ana denkleme $\Delta \mathrm{REK}_{\mathrm{t}-1}$ konulup tahmin edilemez. Çünkü $\Delta \mathrm{REK} \mathrm{K}_{\mathrm{t}}$ ve $\Delta \mathrm{REK} \mathrm{t}_{\mathrm{t}-1}$ birçok gecikmeli değerleri tahminde olacağ 1 için OLS tahmininde sorun çıkacaktır. (X'X) ${ }^{-1} X^{\prime} y$ hesap edilemez. Çoklu doğrusal bağlantı nedeniyle X'X matris derecesi k'dan daha az olacağı için tersi alınamaz. ARDL modelinde $\triangle \mathrm{REK}_{\mathrm{t}-1}$ olmadan tahmin edilmiştir. ARDL gecikme satırına bakıldığında son değişkenin gecikme sayısı AIC tarafından sıfır belirlendiği için $\Delta \mathrm{REK}_{\mathrm{t}-1}$ için tahmin sonuçları elde edilememiştir.

Model $3 \Delta \mathrm{REK}_{\mathrm{t}-1}$ ifadesi ile birlikte el yordamıla ARDL tahmini yapılmış ve Tablo 3'de rapor edilen sonuçlara oldukça yakın sonuçlar elde edilmiştir. Bu yüzden el yordamıyla yapılan tahmin rapor edilmemiştir. 
dikkate aldığı varsayılan modeldir. Her bir model A ve B olarak iki kez tahmin edilmiştir. A modelinde merkez bankasının nominal faizlere göre politika belirlediği, B modelinde ise bankalararası gecelik faiz oranına göre politika belirlediği varsayılmıştır.

Orijinal Taylor kuralı tahmin edildiğinde çıktı düzeyi katsayısının anlamsız olduğu görülmüş̧tür. Aynı şekilde bu modelde enflasyon açığına ait katsayıda istatistiksel

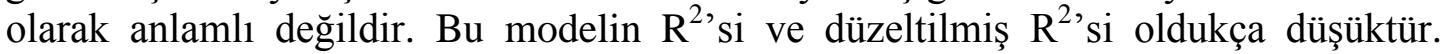
Politika faizi bağımlı değişken olarak kullanıldığında modelde enflasyon açı̆̆ katsayısının negatif ve oldukça yüksek olduğu görülmüştür. Bu katsayı ayrıca istatistiksel olarak anlamlıdır. Bağımlı değişkenin nominal faizler olduğu duruma göre $\mathrm{R}^{2}$ yükselmiş olsa bile halen yeterli düzeyde değildir.

Taylor'un açık ülkeler için önerdiği modeli tahmin ettiğimizde enflasyon oranı istatistiki olarak anlamlı ve çok yüksek bir katsayıya sahip olmasına rağmen çıktı açığ 1 yine bu modelde istatistiki olarak anlamsızdır. Reel döviz kuru katsayıs $\% 10$ seviyesinde ve birinci geçmişinin katsayısı ise \%5 seviyesinde istatistiki olarak anlamlıdır. Modelin $\mathrm{R}^{2}$, si oldukça yüksektir. Bu modeli politika faiz oranı ile tahmin ettiğimizde aynı katsayılar istatistiki olarak anlamlı olduğu gözlemlenmektedir. Buna ek olarak reel döviz kurunun bugünkü değeri artık diğer katsayılar gibi aynı etkiye sahiptir. Fakat modelin açıklama gücünde ciddi düşüş yaşanmıştır.

Mohanty ve Klau modeline geldiğimizde (Model 3) enflasyon döviz kuru ve faiz oranının bir gecikmeli değerine ait katsayılar istatistiki olarak anlamlı iken reel döviz kurundaki değişmeye ait parametre ise yüzde 10 seviyesinde anlamlıdır. Çıktı açı̆̆ bu modelde de istatistiki olarak anlamsızdır. Bu modeli politika faiz oranı ile tahmin ettiğimizde ise katsayıların anlamlılığında herhangi bir değişme olmaz iken enflasyonun etkisi yarı yarıya azalmıştır. Çıktı açığı yine istatistiki olarak anlamsız iken reel döviz kurundaki değişmenin etkisi artmıştır.

Değiştirilmiş Mohanty ve Klau denkleminin tahmini Model 4 olarak tabloya aktarılmıştır. Bağımlı değişken nominal faiz oranı iken tüm değişkenler istatistiki olarak anlamlıdır. Çıktı açı̆̆ı arttığında merkez bankasının nominal faizleri sert bir şekilde düşürmesi gerektiği sonucuna ulaşabiliriz.

Bir sonraki tabloda Peseran ve Shinn (1999) tarafından geliştirilen sınır testi sonuçları yer almaktadır. Düzeyde ve birinci farkı durağan olan serilerimizin arasında herhangi bir koentegrasyon yani uzun dönemli ilişki var $m 1$ sorusunun cevabı aranacaktır. Değiş̧kenlerimizin uzun dönemli ilişkiye sahip olmaması durumunda ARDL ve kısa dönem analizleri çok bir anlam ifade etmeyecektir. Sınır testi sonuçlarına göre dördüncü modelin nominal faiz oranlarının bağımlı değişken olduğu durum dışındaki 
tüm regresyon tahminlerinde uzun dönemli ilişkinin varlığı söz konusudur. Çoğu modelde $\% 1$ seviyesinde uzun dönemli ilişsinin olmadığı yönündeki boş hipotez reddedilmektedir.

Tablo 4. Sınır Testi Sonuçları

\begin{tabular}{|c|c|c|c|c|c|c|}
\hline \multirow{2}{*}{\multicolumn{2}{|c|}{ Model }} & \multirow{2}{*}{$\begin{array}{c}\text { Bağımsız } \\
\text { Değişken } \\
\text { Sayısı } \\
(\mathrm{k})\end{array}$} & \multirow{2}{*}{ F testi } & \multicolumn{3}{|c|}{$\begin{array}{c}\text { Kritik Değerler } \\
\text { [ Üst Sira I(0) Alt Sira I(1)] }\end{array}$} \\
\hline & & & & $10 \%$ & $5 \%$ & $1 \%$ \\
\hline \multirow{2}{*}{ Model 1} & $\mathrm{~A}$ & \multirow{2}{*}{2} & $13.47 * * *$ & 2.17 & 2.72 & 3.88 \\
\hline & $\mathrm{B}$ & & $10.33 * * *$ & 3.19 & 3.83 & 5.3 \\
\hline \multirow{2}{*}{ Model 2} & A & \multirow{2}{*}{3} & $8.00 * * *$ & 2.01 & 2.45 & 3.42 \\
\hline & $\mathrm{B}$ & & $3.19 *$ & 3.1 & 3.63 & 4.84 \\
\hline \multirow{2}{*}{ Model 3} & $\mathrm{~A}$ & \multirow{2}{*}{3} & $6.51 * * *$ & 2.37 & 2.79 & 3.65 \\
\hline & B & & $3.26^{*}$ & 3.2 & 3.67 & 4.66 \\
\hline \multirow{2}{*}{ Model 4} & A & \multirow{2}{*}{3} & 2.11 & 2.37 & 2.79 & 3.65 \\
\hline & $\mathrm{B}$ & & $4.88 * * *$ & 3.2 & 3.67 & 4.66 \\
\hline
\end{tabular}

* Uzun dönemli ilişkinin istatistiksel olarak \%10, 55 ve \%1 seviyelerinde olduğu sırası ile *,** ve *** işaretleri ile $\mathrm{F}$ testinde gösterilmiştir.

Dördüncü modelde nominal faizler bağımlı değişken iken hesaplanan F testi alt sınır kritik değerlerinin altındadır. Bu durumda değişkenlerin $\mathrm{I}(0)$ olduğu yani aralarında eşbütünleşmenin olmadığı sonucuna ulaşılmıştır. İkinci ve üçüncü modelde politika faizi bağımlı değişken iken sadece \%10 seviyesinde boş hipotez reddedilmektedir. $\% 5$ ve \%1'lik seviyelerde ise kararsız bölgede kalınmaktadır. Bu üç model haricinde diğer tüm modellerin her versiyonunda boş hipotez \%1'lik istatistiki seviye reddedilmektedir. Yani değişkenler arasında eşbütünleşme için güçlü kanıtlar elde edilmiştir. Sınır testi sonucuna göre 5 modelde kuvvetli eşbütünleşmenin varlığına dair sonuçlar elde edilirken, iki modelde zayıf sonuçlar elde edilmiştir. Sadece bir modelde eşbütünleşmenin varlığını reddeden boş hipotez reddedilememiştir.

Eşbütünleşme sonuçları Tablo 5'de yer almaktadır. Uzun dönemli sonuçlara baktığımızda sınır testine göre model 1'de hem nominal faiz oranları hem de politika faiz oranı bağımlı değişken iken eşbütünleşmenin varlığına ulaşmamıza rağmen uzun dönemli katsayılar istatistiki olarak anlamlı değildir. İkinci modelde nominal faiz oranı bağımlı değişken iken çıktı açığının uzun dönemde nominal faizleri etkilemediğine dair istatistiki kanıt elde edilmiştir. Enflasyon oranı nerdeyse uzun dönemde nominal faizleri bire bir etkilerken reel döviz kurunun etkisi \%1 civarındadır. Bu modelde politika faizi bağımlı değişken iken reel döviz kurunun etkisinin olmadığı sonucuna ulaşılmıştır. Çıktı açığının etkisi oldukça kuvvetlidir. 
Çıktı açığı yüzde 1 arttığında nominal faizler yüzde 2,32 artması gerektiği sonucuna ulaşılmıştır. Enflasyonun etkisi nominal faizlere göre yüzde 20 daha fazla ve katsayı nerdeyse bire yaklaşmıştır.

Tablo 5. Uzun Dönem Katsayıların Tahmini

\begin{tabular}{|c|c|c|c|c|c|c|c|c|}
\hline \multirow{2}{*}{ Değişken } & \multicolumn{2}{|c|}{ Model 1} & \multicolumn{2}{|c|}{ Model 2} & \multicolumn{2}{|c|}{ Model 3} & \multicolumn{2}{|c|}{ Model 4} \\
\hline & A & B & A & B & A & B & A & B \\
\hline \multirow{2}{*}{ Çıktı Açı̆̆ı } & -0.013 & 111.613 & 20.893 & 232.092 & 27.680 & 233.286 & 263.206 & 1808.929 \\
\hline & $(0.010)$ & $(121.7)$ & $(12.620)$ & $(46.5)^{* * *}$ & $(17.075)$ & $(46)^{* * *}$ & $(221.33)$ & $(998)^{*}$ \\
\hline \multirow{2}{*}{ Enflasyon Açı̆̆ı } & -0.00005 & -2.075 & - & - & - & - & -7.510 & -27.271 \\
\hline & $(0.000056)$ & $(1.300)$ & - & - & - & - & $(4.866)$ & $(14.86)^{*}$ \\
\hline \multirow{2}{*}{ Enflasyon } & - & - & 0.852 & 0.983 & 0.818 & 0.979 & - & - \\
\hline & - & - & $(0.014)^{* * * *}$ & $(0.045)^{* * *}$ & $(0.028)^{* * *}$ & $(0.049)^{* * *}$ & - & - \\
\hline \multirow{2}{*}{ Rek } & - & - & 0.098 & 0.012 & - & - & -2.423 & -4.339 \\
\hline & - & - & $(0.012)^{* * *}$ & $(0.022)$ & - & - & $(0.665)^{* * *}$ & $(2.036)^{* *}$ \\
\hline \multirow{2}{*}{$\Delta$ Rek } & - & - & - & - & -0.504 & -2.851 & - & - \\
\hline & - & - & - & - & $(0.262)^{*}$ & $(0.966) * * *$ & - & - \\
\hline \multirow{2}{*}{ Sabit } & - & - & - & - & 10.736 & 1.242 & 263.689 & 430.950 \\
\hline & - & - & - & - & $(2.136)^{* * *}$ & $(2.517)$ & $(61.59)^{* * *}$ & $(185.9)^{* * *}$ \\
\hline
\end{tabular}

* Parantez içindeki ifadeler standart hatalar olup, ***,** ve* işaretleri sırası ile ilgili katsayının $\% 1, \% 5$ ve $\% 10$ düzeyinde istatistiksel olarak anlamlı olduğunu göstermektedir. Modeli seçerken Akaike bilgi Kriteri tercih edilmiştir. Ayrıca model Newey-West yöntemiyle tahmin edildiği için otokorelasyon ve farklı varyans testleri uygulanmamıştır.

Üçüncü modelde nominal faizler bağımlı değişken iken çıktı açığının katsayısı istatistiki olarak anlamlı değildir. Reel döviz kurundaki değişmenin katsayısı ise yüzde 10 seviyesinde anlamlıdır. Enflasyonun etkisi yüzde 80 iken reel döviz kurundaki değişmenin etkisi negatif ve yüzde 50 civarındadır. Politika faizi bağımlı değişken iken sabit hariç tüm katsayılar istatistiki olarak oldukça anlamlıdır. Çıktı açığının etkisi bir önceki modeldekine yakındır. Enflasyon açığı içinde benzer bir durum söz konusudur. Reel döviz kurunda artış olduğunda nominal faizlerde bu artışın yarısı kadar azalmaya neden olduğu bulunmuştur.

Dördüncü modelde ise nominal faizler bağımlı değişken iken sadece reel döviz kuru istatistiksel olarak anlamlıdır. Diğer değişkenler için sıfır olduğu boş hipotez reddedilememiştir. Reel döviz kurunun etkisi Taylor'ın önerdiği açık ekonomiler için modeldekine göre etkisine göre hem ters yönlü hem de neredeyse 25 kat daha fazladır. Politika faizi bağımlı değişken olduğu durumda ise hem çıktı açığı hem de enflasyon açığı yüzde 10 seviyesinde istatistiki olarak anlamlıdır. Reel döviz kuru ise yüzde 1 seviyesinde anlamlıdır. Enflasyon açığı ve reel döviz kuru ile politika faizi ters orantılıdır. Fakat çıktı açığı ile politika faizi arasında pozitif ilişki vardır.

Tablo 6'da hata düzeltme modeli katsayıları yer almaktadır. Öncelikle genel bir değerlendirme yapacak olursak eşbütünleşme denklemi katsayısı tüm modellerde istatistiksel olarak oldukça yüksek bir anlamlılık düzeyine sahiptir. Ama çıktı 
açı̆̆ının kısa dönem katsayısı tüm modeller için maalesef istatistiksel olarak anlamlı değildir. Bağımlı değişken nominal faiz iken bağımlı değişkene ait kısa dönemli katsayı tüm dört model içinde istatistiki olarak en kötü ihtimalle \%10 seviyesinde anlamlıdır. Bağımlı değişken politika faizi olduğunda ise sadece model 4'de istatistiki olarak anlamlıdır.

Enflasyon açığı ise sadece birinci modelde bağımlı değişken politika faizi iken ve dördüncü modelde bağımlı değișken nominal faiz iken anlamlıdır. Diğer iki tahminde ise istatistiki olarak anlamlı değildir. Enflasyonun ve reel döviz kurunun kısa dönemli katsayısı tüm tahminlerde istatistiksel olarak anlamlıdır. Enflasyonun katsayısı pozitif iken reel döviz kurunun katsayısı negatiftir.

Tablo 6. Hata Düzeltme Modelinin Sonuçları

\begin{tabular}{|c|c|c|c|c|c|c|c|c|}
\hline \multirow{2}{*}{ Değişken } & \multicolumn{2}{|c|}{ Model 1} & \multicolumn{2}{|c|}{ Model 2} & \multicolumn{2}{|c|}{ Model 3} & \multicolumn{2}{|c|}{ Model 4} \\
\hline & A & B & A & $\mathrm{B}$ & A & $\mathrm{B}$ & A & $\mathrm{B}$ \\
\hline \multirow[b]{2}{*}{ D(Faiz/Politika Faizi) } & -0.163 & -0.134 & 0.222 & -0.135 & 0.190 & -0.135 & -0.189 & -0.380 \\
\hline & $(0.097)^{*}$ & $(0.084)$ & $(0.118)^{*}$ & $(0.136)$ & $(0.105)^{*}$ & $(0.117)$ & $(0.093)^{* *}$ & $(0.111)^{* * *}$ \\
\hline \multirow[b]{2}{*}{$\mathrm{D}($ Çıktı Açı̆̆ı) } & 0.011 & 9.923 & -19.620 & -39.582 & -17.775 & -41.690 & -20.052 & -25.276 \\
\hline & $(0.010)$ & $(36.03)$ & $(13.870)$ & $(45.110)$ & $(14.01)$ & $(45.13)$ & $(14.97)$ & $(44.69)$ \\
\hline \multirow[b]{2}{*}{ D(Enflasyon Açığı) } & 0.000005 & -0.774 & - & - & - & - & 0.565 & -0.490 \\
\hline & $(0.00006)$ & $(0.2) * * *$ & - & - & - & - & $(0.130)^{* * *}$ & $(0.412)$ \\
\hline \multirow[b]{2}{*}{$\mathrm{D}$ (Enflasyon) } & - & - & 0.852 & 0.828 & 0.846 & 0.815 & - & - \\
\hline & - & - & $(0.1)^{* * * *}$ & $(0.39)^{* *}$ & $(0.1)^{* * * *}$ & $(0.4) * *$ & - & - \\
\hline \multirow[b]{2}{*}{$\mathrm{D}(\mathrm{REK})$} & - & - & -0.296 & -1.398 & -0.340 & -1.417 & -0.420 & -1.625 \\
\hline & - & - & $(0.1)^{* * *}$ & $(0.3)^{* * *}$ & $(0.07)^{* * * *}$ & $(0.2)^{* * *}$ & $(0.11)^{* * *}$ & $(0.28)^{* * *}$ \\
\hline \multirow[b]{2}{*}{ CointEq(-1) } & -0.881 & -0.319 & -0.658 & -0.468 & -0.620 & -0.442 & -0.059 & -0.062 \\
\hline & $(0.14)^{* * * *}$ & $(0.06)^{* * * *}$ & $(0.11)^{* * *}$ & $(0.11)^{* * * *}$ & $(0.1)^{* * * *}$ & $(0.1)^{* * * *}$ & $(0.02)^{* * *}$ & $(0.01)^{* * * *}$ \\
\hline
\end{tabular}

* Parantez içindeki ifadeler standart hatalar olup, ****** ve* işaretleri sırası ile ilgili katsayının $\% 1, \% 5$ ve $\% 10$ düzeyinde istatistiksel olarak anlamlı olduğunu göstermektedir. Modeli seçerken Akaike bilgi Kriteri tercih edilmiştir. Ayrıca model Newey-West yöntemiyle tahmin edildiği için otokorelasyon ve farklı varyans testleri uygulanmamıştır.

Ekonometrik yöntemlerden elde ettiğimiz tüm sonuçları kısa özetleyecek olursak, orijinal Taylor kuralının Türkiye için geçerli olmadığı kanısına varılmıştır. Çünkü denklem özellikle gelişmekte olan ülkeler için önemli bir etkiye sahip olan döviz kurunu içermemektedir ve tahmin edilen modelin açıklama gücü oldukça düşük düzeydedir. 
Taylor tarafından 2001 yllında açık ekonomiler için önerilen model tahmin edildiğinde nominal faizlerde gelirin politika faizinde ise reel döviz kurunun modeli açıklama yönelik katkısının anlamlı olmadığı sonucuna ulaşılmıştır. Ayrıca modelin açılama gücü orijinal taylor kuralına göre artmış olsa bile yeterlidir değildir.

Mohanty-Klau modeli ise merkez bankası davranışı açıklamaya yönelik iyi bir model olduğunu söyleyebiliriz. Modelin açıklama gücü \%96 civarındadır. Fakat çıktı açığının katsayısı istatistiki olarak anlamlı değildir. Uzun dönemde de çıktı açığının açıklama gücünün olmadığını ileri süren bir modeldir. Bu modelde bağımlı değişken politika faizi iken çıktı açığı istatistiksel olarak anlamlı olsa bile modelin açıklama gücü yaklaşık \%20 azalmıştır.
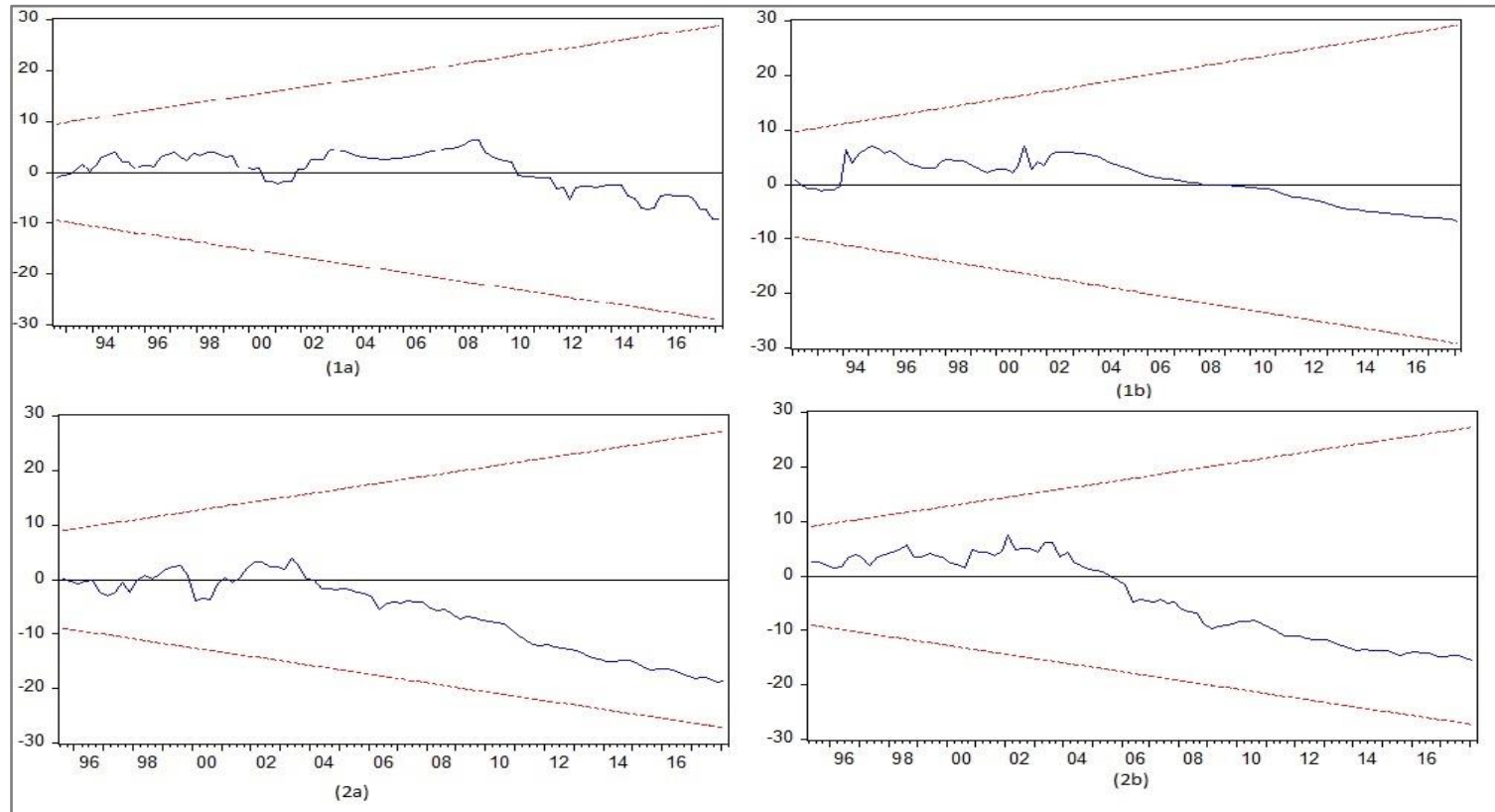

Grafik 1. Cusum Test Sonuçları

* Kırmızı kesikli çizgiler \%5 alt ve üst bandı temsil etmektedir.

Değiştirilmiş Mohanty-Klau modelinin Türkiye ekonomisine en uygun model olduğunu söyleyebiliriz. ARDL sonuçlarında bağımlı değişken nominal faiz oranları iken çıktı açığı istatistiksel olarak anlamlı iken sınır testi yaklaşımına göre bu modelde değiş̧enler arasında istatistiksel olarak herhangi bir ilişki uzun dönemde mevcut değildir. Fakat politika faizi bağımlı değişken olarak kullanıldı̆̆ında hem sınır testi uzun dönemli ilişkinin varlı̆̆ına işaret etmekte hem de uzun dönem denkleminde tüm katsayılar istatistiki olarak anlamlıdır. Bu koşullar göz önüne 
alındığında TCMB'nin davranışını en iyi açıklayan modelin bağımlı değişkeni politika faiz oranıdır. Dördüncü model veya değiştirilmiş Mohanty-Klau denkleminin TCMB'nin davranışını en iyi açıklayan model olduğu sonucuna ulaşılmıştır.

Yukarıda regresyon sonuçları yorumlanan modellerin sağlamlık/tutarlılık (robust) testlerinin de sunulması gerekmektedir. Aksi takdirde bu yorumların ne kadar sağlıklı olduğu konusunda hep şüphe kalacaktır. İki tane sağlamlık testi uygulanmamıştır. Bunlardan ilki tahmin edilen katsayllar cusum testine tabi tutulmuştur. İkincisi ise ARDL modelinde ARMA yapısı olduğu için tahmin edilen modelin ARMA karakteristik polinomlarının ters kökleri hesaplanıp birim çember ile grafikleştirilmiştir. Grafik 1 ve 2'de tüm modellerin cusum testleri yer almaktadır. Cusum testi modelde tahmin edilen katsayıların kararlı veya modelde yapısal kırılma olup olmadığı hakkında önemli ip uçları vermektedir. Birinci modelde nominal faizler bağımlı değişken iken cusum testi sık sık işaret değiştirmiştir. Bu yapı modeldeki katsayıların durağan olduğu konusunda kanı uyandırmıştır. Modelde bağımlı değişken politika faiz oranı ise bu durumda artı eksi dönüşme sıklığının azaldığ 1 görülmektedir. İlk testte olduğu gibi tüm katsayılar $\% 5$ alt ve üst sınır değerlerinin arasında kalmaktadır. Benzer yorumları diğer modeller içinde yapabiliriz.
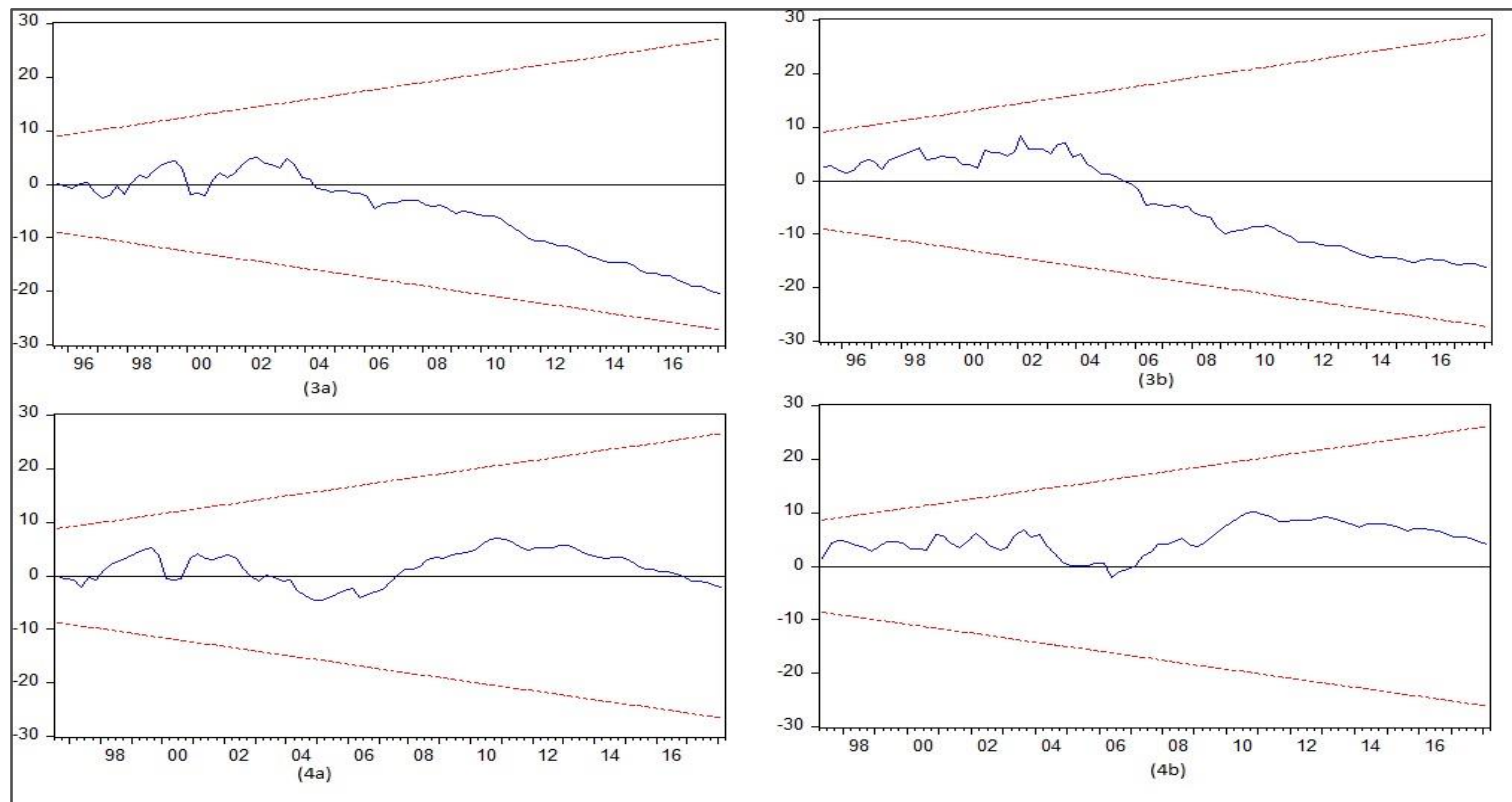

\section{Grafik 2. Cusum Test Sonuçları (Devam)}

* Kırmızı kesikli çizgiler \%5 alt ve üst bandı temsil etmektedir. 
Bir sonraki tutarlılık testi ise ARMA polinominal ters köklerinin hesaplanmasıdır. Grafik 3'te ARMA yapısının ters kökleri birim çember üzerinde her bir model için
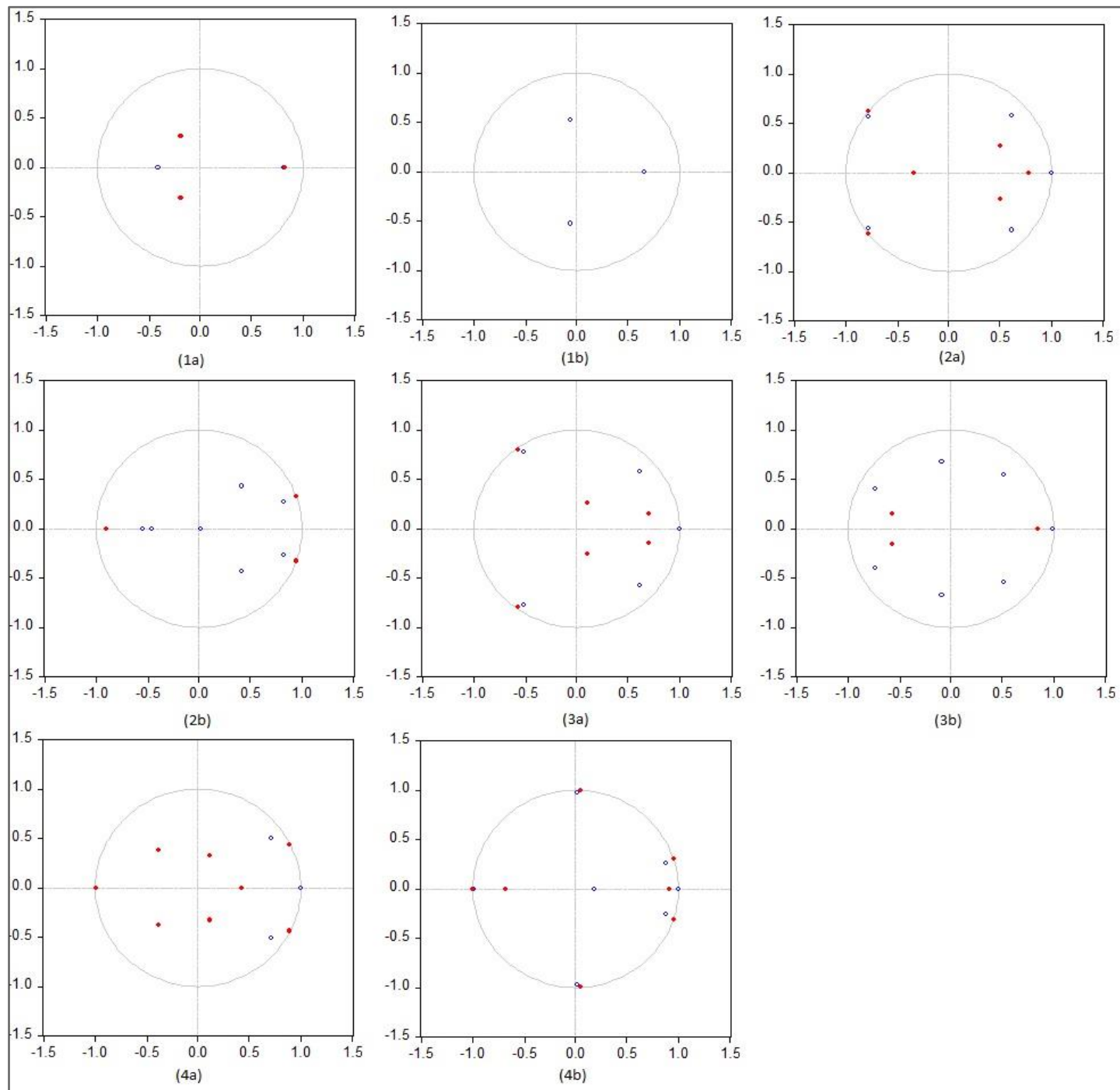

Grafik 3. ARMA Polinomal Test Kökler

* Mavi noktalar otoregresif yapının ters köklerini temsil ederken, kırmızı noktalar hareketli ortalamaların ters köklerini temsil etmektedir.

** ARMA polinominal ters kökleri hesaplanırken ARDL modelde otoregresif AR(p) ve hareketli ortalamalar MA(q) değerlerinin en yükseği ARMA yapısı olarak tahmin edilip, AR/MA kök grafiği oluşturulmuştur. Örneğin Tablo 3'de ARDL gecikme Model 3 için $(7,0,3,0)$ göstermektedir. AR/MA kökleri hesaplanırken tüm bağımlı değişkenler için gecikme 3 kabul edilmiştir. $\operatorname{Yani} \operatorname{Ar}(7) \operatorname{MA}(3)$ tahmin edilmiş ve polinominal ters kökler hesaplanmıştır. Eğer bu model durağan/kararlı ise $(7,0,3,0)$ de kararlıdır. 
gösterilmiştir. ARMA yapısının kararlı/durağan olabilmesi için polinominal ters köklerin birim çember içinde olması gerekmektedir. Eğer polinominal yapının ters köklerinde biri bile birim çember dişında ise bu durumda bu yapının patlayan bir denkleme sahip olduğu veya uzun dönemde dengeye gelemeyeceğine dair kanıtlar elde etmiş oluruz. Fakat bu polinominal ters köklerin tümü birim kök içinde veya üzerinde ise bu durumda tahmin edilen modelin kararlı olduğu veya uzun dönemde dengeye geleceğine dair istatistiki kanıtlar elde etmiş oluruz.

Grafik 3'e baktığımızda model 1 tahmininde bağımlı değişken fark etmeksizin her iki tahminde de polinominal ters köklerin birim çember içinde olduğu görülmektedir. Yani model 1 tahmini kararlıdır. Benzer açıklamaları diğer modeller içinde yapılabilir. Örneğin model 3b'ye baktığımızda üç otoregresif kök ve sekiz adet hareketli ortalamalar yapısından kaynaklanan köklerin birim çember içinde olduğu gözlemlenmektedir. Model 3b'nin uzun dönemde kararlı dengeye varacağ 1 sonucuna ulaşılır.

\section{Sonuç}

Enflasyon problemi hem gelişmiş hem de gelişmekte olan ülkeler için başa çıkılması gereken en temel ekonomik problemlerin başında yer almaktır. 1970'lerde yaşanan petrol krizi ile birlikte dünya ekonomilerinde yeniden hortlayan enflasyonu azaltmak için çeşitli ekonomik önlemler devletler tarafından uygulanmıştır. 1930'larda başlayan ekonomik gösterge hedefi veya kurallı para politikası tartışması 1980'lerde tekrardan alevlenmiştir. Taylor kendi adına atıf yapılan kural ile bu tartışmaya yeni bir boyut kazandırmıştır. Bu çalışmadan sonra kurallı para politikasının enflasyonu önleme üzerine etkileri hakkında birçok çalışma yapılmıştır. İleriki dönemlerde çeşitli değişkenler ile yeni türleri ortaya çıkan ve ekonomi yazınında uyarlanmış Taylor kuralı olarak adlandırılan birçok model ülkeler için tahmin edilmiştir.

Bu çalışmada orijinal Taylor kuralı ve gelişmekte olan ülkelere uyarlanmış 3 farklı Taylor tipi kural Türkiye ekonomisi için çeyreklik veriler kullanılarak 1990:01 2018:01 arası geçerliliği sınanmıştır. Bu kurallardan hangisinin TCMB'nin davranışını daha iyi açıklayabildiği sorusunun cevabı aranmıştır. Seçilen kural çerçevesinde hangi değişkenin faiz oranları üzerinde ne kadarlık bire etkiye sahip olduğuna bakılmıştır.

Çalışmada uygulanan ekonometrik yöntemlerden elde dilen bulgular TCMB'nin davranışını en iyi açıklayan modelin değiştirilmiş Mohanty - Klau denkleminin Türkiye Cumhuriyet Merkez Bankası'nın davranışını en iyi açıklayan model olduğu kanısına ulaşılmıştır. Tüm modellerde kısa dönemde TCMB, faiz kararı verirken enflasyon hedefinden sapma miktarına ve reel döviz kurunu dikkate alırken çıktı 
açığını ihmal ettiği sonucuna ulaşılmıştır. Bu sonuç aslında yüksek enflasyonu uzun bir süre yaşayan bir ekonomi için kaçınılmazdır. Çünkü enflasyon ekonomik birimlerde atalet yerleşmesine neden olacaktır ve bu davranış üretim açığını da etkileyecektir. ARDL tahmin sonuçlarına göre enflasyondan sapma arttığında veya reel döviz kurunda artış olduğunda MB politika faizini arttırmaktadır. Reel döviz kurunun bir dönem önceki değeri ve bir dönem önceki politika faizi bugünkü politika faizi üzerinde ciddi bir etkiye sahiptir. Uzun dönemde ise enflasyon açığı ve reel döviz kuru politika faizi ile ters yönlü bir ilişkiye sahiptir. Fakat çıtı açığı ile politika faizi arasında pozitif bir ilişki bulunmuştur. Yani çıktı açı̆̆ çoğunlukla negatif sayı olduğu için- MB'nin politika faizini düşürmesi gerekmektedir.

\section{Kaynakça}

Aklan, N.A. ve Nargeleçekenler, M. (2008), Taylor rule in practice: Evidence from Turkey. International Advanced Economic Resources, 14(2):156-166

Albayrak, N. ve Abdioğlu, Z. (2015). Geriye ve ileriye dönük para politikas1 reaksiyon fonksiyonlarının tahmini: Taylor kuralı. Süleyman Demirel Üniversitesi İktisadi ve İdari Bilimler Fakültesi Dergisi, 20(4), 141-164

Almounsor, A. H. (2015), Monetary policy in Saudi Arabia: A Taylor-rule analysis. International Journal of Economics and Finance, 7(3), 144-152

Ardor, H. ve Varlik, H. (2014), İleriye dönük yeni keynesyen para politikası reaksiyon fonksiyonunun tahmini: Taylor Kuralı'nın, Mccallum Kuralı'nın, Taylor-Mccallum Melez Kuralı'nın Türkiye ekonomisinde geçerliliği. Ekonomik Yaklaşım, 24(89), 45-71.

Bal H., Tanriöver, B., ve Erdoğan, E. (2016), Taylor kuralı kapsamında merkez bankas1 politika faiz oranlarının belirlenmesi: Stokastik trend yaklaşımı. International Journal of Academic Values Studies, (7), 95-106.

Ball, L., (1999), Policy Rules for Open Economies. J. Taylor (Ed), Monetary policy rules, NBER Working Paper (6760).

Beckmann, J., Belke, A., ve Dreger, C. (2017), The relevance of international spillovers and asymmetric effects in the Taylor rule. The Quarterly Review of Economics and Finance, 64, 162-170.

Berument, H. ve Taşçi, H. (2004). Monetary policy rules in practice: Evidence from Turkey. International Journal of Finance \& Economics, 9(1), 33-38. 
Castro, V. (2011), Can Central Banks' monetary policy be described by a linear (augmented) Taylor rule or by a nonlinear rule?. Journal of Financial Stability, 7(4), 228-246.

Çağlayan, E., \& Astar, M. (2010), Taylor rule: Is it an applicable guide for inflation targeting countries. Journal of Money Investment and Banking, 18, 55-67.

Çağlayan, E., (2005), Türkiye'de Taylor Kuralı'nın geçerliliğinin ekonometrik analizi. Marmara Üniversitesi İktisadi ve İdari Bilimler Fakültesi Dergisi, 20(1), 379-392.

Demirbaş, E., ve Kaya, M. V. (2012), Testing the Validity of taylor principle for Turkey from a different perspective. Abant Izzet Baysal Üniversitesi Sosyal Bilimler Enstitüsü Dergisi, 12, 81-110

Depalo, D. (2006). Japan: the case for a Taylor rule? A simple approach. Pacific Economic Review, 11(4), 327-546.

Dickey, D. A., ve Fuller, W. A. (1979). Distribution of the estimators for autoregressive time series with a unit root. Journal of the American statistical association, 74(366a), 427-431.

Dwyer, G. P. (1993). Rules and discretion in monetary policy. Review-Federal Reserve Bank of Saint Louis, 75, 3-3.

Erdal, F. ve Güloğlu, B. (2005). Modelling real exchange rate behaviour with the Taylor rule: An empirical analysis. In Proc. The International Conference on Policy Modeling, EcoMod, Istanbul.

EViews, (2015). Eviews 9 User's Guide. IHS Global Inc

Gögül, P. K., ve Songur, M. (2016). Türkiye'de enflasyon hedeflemesi stratejisinde araç kural "Taylor Kuralı" mı?(2006-2015). Maliye Araştırmaları Dergisi, 2(1).

Gözgör, G. (2012). Inflation targeting and monetary policy rules: Further evidence from the cse of Turkey. Journal of Applied Finance and Banking, 2(5), 127

Granger, W., ve Newbold, P. (1974). Spurious regressions in econometrics. Journal of Econometrics, 2(2), 111-120. 
Hodrick, R. J., ve Prescott, E. C. (1997). Postwar US business cycles: an empirical investigation. Journal of Money, credit, and Banking, 29(1), 1-16.

Judd, J. P., ve Rudebusch, G. D. (1998). Taylor's Rule and the Fed: 19701997. Economic Review-Federal Reserve Bank of San Francisco, 3-16.

Kaytancı, B. G. (2008). Para politikası kurallarının teorik analizi: Bazı basit kuralların incelenmesi. Eskişehir Osmangazi Üniversitesi İ̈BF Dergisi, 3(1), $11-25$.

Kesriyeli, M., ve Yalçın, C., (1998). Taylor kuralı ve Türkiye uygulaması üzerine bir not. TCMB, Araştırma Genel Müdürlüğü, Tartışma Tebliği No:9802.. https://web.archive.org/ web/ 20070703002437 /http://www.tcmb.gov. tr:80 /research /discus/dpaper3.html (01.08.2018)

Kim, D. H., Osborn, D. R., ve Sensier, M. (2005). Nonlinearity in the Fed's monetary policy rule. Journal of applied Econometrics, 20(5), 621-639.

Kwiatkowski, D., Phillips, P. C., Schmidt, P., ve Shin, Y. (1992). Testing the null hypothesis of stationarity against the alternative of a unit root: How sure are we that economic time series have a unit root?. Journal of Econometrics, 54(1-3), 159-178.

MacKinnon, J. G. (1994), Approximate asymptotic distribution functions for unitroot and cointegration tests. Journal of Business and Economic Statistics, 12 $167-176$

Mankiw, N. G. (2007). Macroeconomics,(Edition 6). Worth Publisher, New York.

McCallum, B. T. (1987). the case for rules in the conduct of monetary policy: A concrete example. Review of World Economics, 123(3), 415-429.

McCallum, B. T. (1988). Robustness properties of a rule for monetary policy. In Carnegie-Rochester conference series on public policy. 29, pp. 173-203

Miyazawa, K. (2011). The Taylor rule in Japan. Japanese Economy, 38(2), 79-104.

Mohanty, M. ve M. Klau, (2003), Monetary policy rules in emerging market economies 1ssues and evidence. Bank for International Settlements, (çevrimiçi) http://www.bis.org/publ/work149. pdf, 16.06.2018. 
Nelson, E. (2001). UK monetary policy 1972-97: A guide using Taylor Rules. Bank of England Working Paper

Nitschka, T., ve Markov, N. (2016). Semi- parametric estimates of taylor rules for a small, open economy-evidence from Switzerland. German Economic Review, 17(4), 478-490.

Omay, T. ve Hasanov, M., (2010). Türkiye için Reaksiyon fonksiyonunun doğrusal olmayan modelle tahmin edilmesi. Çankaya University Journal of Humanities and Social Sciences, 7(2), 467-490.

Ongan, H., (2004). Enflasyon hedeflemesi ve Taylor kuralı: Türkiye örneği. Maliye Araştırma Merkezi Konferansları, 45,1-12.

Onur, S. (2008). Türkiye Ekonomisi'nde faiz oranlari-enflasyon ilişkisi üzerine bir model denemesi (1980-2005). Journal of Qafqaz University, (24).

Ozcan, M. (2016). Asymmetric taylor monetary rule: The case of Turkey. Eurasian Academy of Sciences Social Sciences Journal, 10, 68-92

Pehlivanoğlu, F. (2014). Optimal Para politikasi çerçevesinde Taylor tipi faiz oranı reaksiyon fonksiyonun tahmini: Türkiye örneği. Bilgi Ekonomisi ve Yönetimi Dergisi, 9(1). 115-126

Perruchoud, A. (2009). Estimating a Taylor rule with Markov switching regimes for Switzerland. Swiss Journal of Economics and Statistics, 145(2), 187-220.

Pesaran, M.H. ve Shinn, Y. (1999), An Autoregressive distributed lag modelling approach to cointegration analysis, S. Strom (Ed), Econometrics and Economic theory in the 20th Century. The Ragnar Frisch Centennial Symposium. Cambridge: Cambridge University Press, Ch. 11.

Phillips, P. C. B., ve P. Perron. 1988. Testing for a unit root in time series regression. Biometrika, 75: 335-346

Sack, B. ve Wieland, V. (2000). Interest-rate smoothing and optimal monetary policy: a review of recent empirical evidence. Journal of Economics and Business, 52(1-2), 205-228.

Sghaier, I. M. (2012). Taylor rule and monetary policy in Tunisia. Romanian Economic Journal, 15(46). 
Sutherland, D. (2010.). Monetary policy reaction functions in the OECD. OECD Economics Department Working Paper No. 761

Taylor, J. B. (1993). Discretion versus policy rules in practice. In Carnegie-Rochester Conference Series On Public Policy, 39, 195-214

Taylor, J. B. (2001). The role of the exchange rate in monetary-policy rules. American Economic Review, 91(2), 263-267.

Villa, E., Misas, M. A. ve Giraldo, A. F. (2014). Inflation targeting and an optimal taylor rule for an open economy: Evidence for Colombia 1990-2011. Latin American Journal of Economics, 51(1), 41-83.

Yazgan, M. E. ve Yilmazkuday, H. (2007) Monetary rules in practice: Evidence from Turkey and Israel. Applied Financial Economics, 17: 1-8.

Yıldırım, E., Lopcu, K., Çakmakli, S., ve Özkan, Ö. (2010). Yeni Keynesyen makro ekonomik bir model: Türkiye Uygulaması. Ege Akademik Bakis, 10(4), 12691277 .

Zheng, T., Xia, W., ve Huiming, G. (2012). Estimating forward-looking rules for china's monetary policy: A regime-switching perspective. China Economic Review, 23(1), 47-59.

Zortuk, M. (2007). Koşulluluk aracı olma bağlamında kisa vadeli faiz oranlarının hedeflenen enflasyondan sapmada kullanımı: Bounds test yaklaşimi (Türkiye Örneği), Ekonometri ve İstatistik e-Dergisi, 6, 41-68. 


\section{Estimating Monetary Policy Reaction Function for Central Bank of Turkey}

\section{Extended Abstract}

\section{Introduction}

Governments have been struggled with inflation in some periods. After governments had adopted Keynesian policy more than 40 years, inflation has burst after 1970s. Some of economist claimed that inflation reappeared because of discretion policy. Indeed, the debate about monetary policy about ruled based or discretion has been started long time ago. Dwyer (1995) reported that Simons (1936) supported ruled based monetary policy against discretion policy due to the fact that ruled based monetary policy promotes entrepreneurship more than the other.

On the other hand, McCallum(1987,1988) criticized ruled based monetary policy. He claimed that central banks should not construct their monetary policy about variables that they do not have a control. For example, even though money stock (M1) is a simple variable, central banks may not control it (M1) because of bank money. Moreover, countries and their institutions have changed over time. But monetary policy based on rules might not capture change in economy or institutions.

Monetary policy discussion had blazed out after Taylor (1993) proposed a monetary policy rule in a conference paper. According to the Taylor's suggestion, FED decision on monetary policy can be explained by equation 1 . After this proposed, many researcher have modified this rule. Bale (1999) and Taylor( 2001) improved Taylor rules for open economies which is added exchange rate in original Taylor rule. After a decade from original proposed, Mohanty and Klau (2003) change the Tylor rule by adding change in real change rate, its first lag, and the lag of nominal interest rate.

In this paper, whether or not original Taylor rule or other types of rules can explain of behavior of Central bank in Turkey. Four different Taylor types of rules are estimated between 1990:01 and 2018:01.

\section{Method}

Equation two, three, four and a different version of the equation 4 are estimated. Output gap and inflation gap are calculated via hp-filter. Also, real exchange rate, nominal interest rate and policy rate (overnight repo rate) is used in estimations. All variables are adopted from CBRT data website. Data is quarterly. Since time series are employed in analysis, it must check those have unit root or not. Furthermore, PP unit root test is run for double check of stationary of time series. After that ARDL approach is preferred to estimation of the reaction function for CRBT.

\section{Results}

Results for ADF unit root test are presented in Table 1. Three different types of ADF test reveals except nominal interest rate and policy rate, all variables are non-stationary. But applying ADF test with only constant or no constant and trend options, real exchange rate is stationary. Moreover, PP unit root test implies that except policy and real gdp, all variables is not stationary at level but if unit root tests are employed for first different of series, all series is stationary. Since some variables is integrated 
order one, -I(1)-, some zero -I(0)-, ARDL approach should be used. Table 3 shows ARDL estimation results. All models is run two times. In the first time (model A), nominal interest rate is dependent variable while in the second version (model B), policy rate is dependent. In the original Taylor rule (model 1A and 1B), almost all variables is not statistically significant and R2 is very low. In the second model, output gap is insignificant. However, all variables are statistically significant in the last model. Also, R2 is very high.

The results of the bond test are reported in Table 4. All estimation unveils significant long-term relation between dependent and independent variables. Unfortunately, only one estimation (model 4A), the null hypothesis cannot be rejected. Also, long term coefficients are found in Table 5. In the last model with policy rate is dependent variable, all long term coefficient statistically highly significant. Other version some of long term coefficients are not significant. Also, robustness test of ARDL estimation (Cusum test and polynomial inverse root of ARMA confirms that these estimation will consistent statistically,

\section{Conclusion}

Inflation is a big phenomenon for both developing and developed countries. After two economics crises in 1970s, this problem has occurred in many countries. After Taylor proposed a rule in a conference, the discussion about rules based or discretion policy has become one of the most intensive research topics in monetary economy. In this study, it is investigated which type of rule may explain better than other for CBRT form 1990:01 to 2018:01. According to the results from ARDL approach, Adaptive Mohanty-Klau rule is that may explain behavior for central bank in Turkey. 